\title{
O PODER NORMATIVO DA AUTORIDADE JUDICIÁRIA: UMA ANÁ- LISE A PARTIR DAS PORTARIAS JUDICIAIS QUE ESTABELECEM O TOQUE DE RECOLHER PARA CRIANÇAS E ADOLESCENTES
}

SUMÁRIO: Introdução; 2 As portarias judiciais do toque de recolher: contextualizando o debate; 3 Os argumentos dos magistrados; 4 Os poderes do juiz no âmbito do Direito da Criança e do Adolescente: comparação entre o ECA e o Código de Menores de 1979; 5 A natureza jurídica do toque de recolber e os limites da autoridade judiciária na área da infância e juventude; 6 Considerações Finais; Referências.

RESUMO: $\mathrm{O}$ artigo tem como objetivo analisar as portarias judiciais que estabelecem o toque de recolher para crianças e adolescentes. A pesquisa apresenta, inicialmente, os argumentos comumente utilizados pelos magistrados para justificar a implementação da restrição. As informações foram retiradas de documentos jurídicos e de uma entrevista realizada com um juiz responsável pelo estabelecimento da medida em sua comarca. Em seguida, faz-se uma comparação entre o Estatuto da Criança e do Adolescente e o Código de Menores de 1979, no que se refere à amplitude dos poderes conferidos aos magistrados que atuam na área da infância e juventude. Por fim, apresenta-se um debate teórico sobre o tema, de forma a permitir uma reflexão sobre a natureza jurídica do toque de recolher e sobre os limites da autoridade judiciária. Conclui-se que o toque de recolher possui um caráter repressivo e que a autoridade judiciária, neste caso, exorbita os poderes conferidos a ela.

PALAVRAS-CHAVE: Código de Menores; Estatuto da Criança e do Adolescente; Poder Judiciário; Portarias judiciais; Toque de recolher.

\section{NORMATIVE POWER OF JURIDICAL AUTHORITY: AN ANALYSIS OF T WO JURIDICAL DECREES THAT ESTABLISH CURFEW FOR CHILDREN AND ADOLESCENTS}

\begin{abstract}
Juridical decrees that establish curfews for children and adolescents are investigated. Research analyzes the arguments usually used by judges for the implementation of the restriction. Data were retrieved from juridical documents and from an interview with a judge responsible for the measure within his jurisdiction. The Statute for Children and Adolescents and the Code for Minors published in 1979 are

\footnotetext{
"Doutora em Ciências Jurídicas e Sociais pelo Programa de Pós-Graduação em Sociologia e Direito da Universidade Federal Fluminense (PPGSD/UFF). Docente Adjunta de Teoria do Direito da Universidade Federal Fluminense (UFF), Brasil. E-mail: andrade_fernanda@hotmail.com
} 
compared with regard to the amplitude of authority conferred to judges who work with children and adolescents. A theoretical debate on the theme discusses the juridical nature of the curfew and on the limits of juridical authority. Results show that curfew has repressive characteristics and, in this case, the juridical authority exceeds the powers conferred.

KEY WORDS: Juridical authority; Curfew; Juridical decrees; Statute of Children and Adolescents; Code for Minors.

\section{EL PODER NORMATIVO DE LA AUTORIDAD JUDICIARIA: ANÁLI- SIS A PARTIR DE LAS PORTERÍAS JUDICIALES QUE ESTABLECEN EL TOQUE DE QUEDA PARA NIÑOS Y ADOLESCENTES}

RESUMEN: En el artículo se tiene como objetivo analizar las porterías judiciales que establecen el toque de queda para niños y adolescentes. La investigación presenta, inicialmente, los argumentos comúnmente utilizados por los magistrados para justificar la implementación de la restricción. Las informaciones fueron retiradas de documentos jurídicos y de una entrevista realizada con un juez responsable por el establecimiento de la medida en su comarca. Después, se hace una comparación entre el Estatuto del Niño y del Adolescente y el Código de Menores de 1979, en lo que se refiere a la amplitud de los poderes conferidos a los magistrados que actúan en el área de la infancia y de la juventud. Por fin, se presenta un debate teórico sobre el tema, de forma a permitir una reflexión sobre la naturaleza jurídica del toque de queda y sobre los límites de la autoridad judiciaria. Se concluye que el toque de queda posee un carácter represivo y que la autoridad judiciaria, en este caso, sobrepasa los poderes conferidos a ella.

PALABRAS CLAVE: Poder Judiciario; toque de queda; porterías judiciales; Estatuto del Niño y del Adolescente; Código de Menores.

\section{INTRODUÇÃO}

$\mathrm{O}$ artigo tem como objetivo analisar a determinação judicial do toque de recolher para crianças e adolescentes. A medida - que consiste na limitação do horário de circulação das pessoas com idade inferior a 18 anos nos logradouros públicos - vem sendo estabelecida por juízes das Varas da Infância e Juventude de diversas comarcas do país, através de portarias judiciais.

O tema suscita debates variados, sendo que uma das principais questões - e 
a que será desenvolvida aqui - se refere à amplitude dos poderes conferidos aos magistrados que atuam na área da infância e juventude. A problemática, embora não seja nova, continua bastante atual, o que justifica um aprofundamento do tema. Do ponto de vista metodológico, o estudo utiliza a pesquisa bibliográfica, a pesquisa documental e a entrevista.

O trabalho está dividido em quatro partes. Inicialmente, na seção 2 é feita uma breve contextualização do tema das portarias judiciais do toque de recolher. Em seguida, na seção 3 são apresentados os argumentos comumente utilizados pelos magistrados no estabelecimento do toque de recolher em suas comarcas. Os dados que constam nesta parte foram coletados através da análise de documentos jurídicos - em especial, portarias judiciais publicadas em cidades onde a medida foi implementada - e também por meio de uma entrevista realizada com um Juiz da Vara da Infância e Juventude de uma das comarcas onde o toque de recolher foi estabelecido ${ }^{02}$.

Na seção 4 faz-se uma comparação entre o Estatuto da Criança e do Adolescente (ECA) - Lei no 8.069, de 13 de julho de 1990 - e o revogado Código de Menores - Lei $n^{\circ} 6.697$, de 10 de outubro de 1979 -, no que se refere à amplitude dos poderes conferidos aos magistrados que atuam na área da infância e juventude.

Por fim, na seção 5 apresenta-se um breve debate teórico sobre o tema, com o intuito de permitir uma reflexão sobre a natureza jurídica do toque de recolher e sobre os limites da autoridade judiciária que atua no âmbito da infância e adolescência.

\section{AS PORTARIAS JUDICIAIS DO TOQUE DE RECOLHER: CONTEXTUALIZANDO O DEBATE}

O tema das portarias judiciais que estabelecem o toque de recolher para crianças e adolescentes ganhou espaço na mídia, principalmente, a partir da implantação da medida no município de Fernandópolis (SP). Embora existam aqueles que defendam que o ineditismo caberia a outras cidades - como Diamantina (MG) e

\footnotetext{
${ }^{02}$ A entrevista foi realizada no dia 02 de setembro de 2010. Optou-se aqui pela manutenção do anonimato do entrevistado. A íntegra da entrevista está disponível em: ALMEIDA, Fernanda Andrade. O juiz "bicho-papão" e a "lei em movimento": um caso de judicialização à brasileira. Niterói: UFF, 2013. Tese de Doutorado - Programa de Pós-Graduação em Sociologia e Direito, Universidade Federal Fluminense.
} 
Imperatriz (MA), por exemplo -, o fato é que a medida ganhou repercussão nacional a partir de sua aplicação no contexto fernandopolense ${ }^{03}$, em $2005^{04}$. Em seguida, a restrição foi estabelecida em diversas outras cidades do país. Em 2009, de acordo com dados do Conselho Nacional de Justiça (CNJ), o toque de recolher já havia sido adotado em 41 municípios de 16 Estados $^{05}$. Contudo, pesquisas posteriores apontaram um número muito superior, que ultrapassaria 70 cidades, em 20 Estados distintos $^{06}$.

Em 2012, o Superior Tribunal de Justiça (STJ) ${ }^{07}$ manifestou-se contrariamente ao toque de recolher, em decisão que discutia restrições impostas às crianças e adolescentes do município de Fernandópolis, estabelecidas através de Portaria expedida pelo Juízo da Infância e Juventude daquela Comarca.

A decisão do STJ foi proferida em um Recurso Especial interposto contra acórdão do Tribunal de Justiça do Estado de São Paulo, que negou provimento à apelação do Ministério Público do Estado de São Paulo, que sustentava a nulidade da referida Portaria.

O acórdão do Superior Tribunal de Justiça, cuja relatoria coube ao Ministro Teori Albino Zavascki, foi no sentido de dar provimento ao Recurso Especial.

${ }^{03}$ Mas é relevante destacar - dentro desta "disputa" pelo pioneirismo da medida - que o próprio juiz responsável pelo toque de recolher em Fernandópolis cita, na portaria que oficializa a ação na cidade - Portaria 03/2009 -, a portaria 1/96, baixada pela Juíza da Infância e da Juventude de Imperatriz (MA). Cf. SÃO PAULO (Estado). Tribunal de Justiça do Estado de São Paulo. Comarca de Fernandópolis. $1^{\mathrm{a}}$ Vara Criminal e Anexo da Infância e da Juventude. Portaria 3/2009. Fernandópolis, 23 mar. 2009b, p. 1.

${ }^{04}$ Antes da Portaria 3/2009, o juiz estabelecia o toque de recolher através de mandados judiciais provisórios, com validade de três meses, que depois eram prorrogados. Em entrevista ao portal de notícias "Terra", o juiz explicou como era o procedimento antes da portaria definitiva: "Primeiro tentamos com mandados judiciais provisórios, válidos por 3 meses, para que, se alguém tentasse derrubar até o processo tramitar, a medida já teria vigorado. [...] Só em 2009 que decidimos adotar de vez esta medida, chamada de toque de recolher". SIQUEIRA, Chico. Juiz diz que Conselho não derruba toque de recolher. Notícias Terra, Araçatuba, 05 jul. 2009. Disponível em: < http://noticias.terra.com.br/brasil/noticias/0,,OI3857319-EI8139,00-Juiz+diz+que+conselho + nao + derruba + toque + de + recolher.html > . Acesso em: 18 out. 2010.

${ }^{05}$ CONSELHO NACIONAL DE JUSTIÇA. Agência CNJ de Notícias. Toque de recolher: comissão do CNJ vai analisar regras para edição de portarias. Notícias, Brasília, 10 nov. 2009. Disponível em: <http://www.cnj.jus. $\mathrm{br} /$ component/content/article/96-noticias/7902-toque-de-recolher-comissao-do-cnj-vai-analisar-regras-para-edicao-de-portarias > . Acesso em: 30 nov. 2009.

${ }^{06}$ GUIMARÃES, Thiago. 72 cidades do Brasil adotam toque de recolher para crianças e jovens, diz juiz. Justiça Atuante (Blog), Itapicuru (BA), 09 jun. 2011. Disponível em: < http://justicaatuante.blogspot.com.br/2011/06/ 72-cidades-do-brasil-adotam-toque-de.html > . Acesso em: 8 dez. 2011. NETTO, José Brandão. 78 cidades já possuem o "toque de acolher" ou recolher. Justiça Atuante (Blog), Itapicuru (BA), 06 jun. 2011. Disponível em: <http:/toquedeacolherbahia.blogspot.com.br/2011/06/78-cidades-ja-possuem-o-de-acolher-ou.html>. Acesso em: 8 dez. 2011.

${ }^{07}$ A decisão foi proferida pela Primeira Turma no julgamento do Recurso Especial 1.292.143/SP, cuja relatoria coube ao Ministro Teori Albino Zavascki. Cf. BRASIL. Superior Tribunal de Justiça. Primeira Turma. Acórdão. Recurso Especial 1.292.143/SP. Recorrente: Ministério Público do Estado de São Paulo. Recorrido: Estado de São Paulo. Relator: Teori Albino Zavascki. Data de Julgamento: 21 jun. 2012. Diário da Justiça Eletrônico (DJe): 07 ago. 2012. Disponível em: <https://ww2.stj.jus.br/processo/revista/inteiroteor/?num_registro $=201102619325 \& d t \_$publicacao $=07 / 08 / 2012>$. Acesso em: 05 jan. 2017. 
Em seu voto, o relator do caso argumentou a partir de uma discussão acerca do poder normativo da autoridade judiciária. Comparando o Código de Menores (Lei 6.697/1979) com o Estatuto da Criança e do Adolescente (Lei 8.069/1990), o Ministro destacou que, nesta última legislação, o poder normativo do juiz seria mais restrito. E acrescentou que estaria evidente, na legislação atual, o propósito do legislador de, "por um lado, enfatizar a responsabilidade dos pais de, no exercício do seu poder familiar, zelar pela guarda e proteção dos menores em suas atividades do dia a dia, e, por outro, preservar a competência do Poder Legislativo na edição de normas de conduta de caráter geral e abstrato" ${ }^{08}$.

Embora tenha prevalecido o entendimento do Relator, a decisão não foi unânime. Em seu voto divergente, o Ministro Napoleão Nunes Maia Filho argumentou que, embora compreendesse a preocupação do Ministro Teori Albino Zavascki, com relação à não intromissão do Poder Judiciário na competência legislativa, entendia que, no caso concreto, existiria uma peculiaridade, em razão do propósito da portaria. Sendo assim, o Ministro concluiu da seguinte forma o seu posicionamento pela manutenção da portaria: "penso que seria o caso de se manter essa portaria e verificar, no decorrer da sua eficácia, se ela produz os resultados esperados pelo Juiz e por nós também"09.

Pode-se observar, a partir da leitura destes posicionamentos apresentados pelos Ministros do STJ na análise do toque de recolher na comarca de Fernandópolis, que os defensores e os opositores da medida oscilam entre argumentos de caráter técnico-normativo - se a medida está ou não de acordo com a lei e, mais especificamente, com o Estatuto da Criança e do Adolescente - e argumentos fáticos - a eficácia da medida no sentido de trazer resultados benéficos aos jovens - na justificativa dos seus pontos de vista.

A manifestação contrária ao toque de recolher proferida pelo STJ em 2012, justamente em um caso envolvendo um município que serviu de inspiração para tantos outros, poderia ser um indício de que haveria um enfraquecimento da medi-

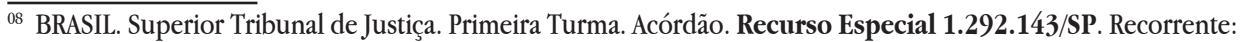
Ministério Público do Estado de São Paulo. Recorrido: Estado de São Paulo. Relator: Teori Albino Zavascki. Data de Julgamento: 21 jun. 2012. Diário da Justiça Eletrônico (DJe): 07 ago. 2012. Disponível em: < https:// ww2.stj.jus.br/processo/revista/inteiroteor/?num_registro $=201102619325 \& d t \_p u b l i c a c a o=07 / 08 / 2012>$. Acesso em: 05 jan. 2017.

${ }^{09}$ BRASIL. Superior Tribunal de Justiça. Primeira Turma. Acórdão. Recurso Especial 1.292.143/SP. Recorrente: Ministério Público do Estado de São Paulo. Recorrido: Estado de São Paulo. Relator: Teori Albino Zavascki. Data de Julgamento: 21 jun. 2012. Diário da Justiça Eletrônico (DJe): 07 ago. 2012. Disponível em: <https:// ww2.stj.jus.br/processo/revista/inteiroteor/?num_registro $=201102619325 \& d t \_$publicacao $=07 / 08 / 2012>$. Acesso em: 05 jan. 2017.
} 
da, seja pela abolição da restrição em algumas comarcas, seja pela ausência de novas adesões ao toque de recolher.

Todavia, não foi o que se verificou. Embora não seja possível mapear, com exatidão, todas as cidades brasileiras que adotam ou já adotaram o toque de recolher para crianças e adolescentes - o que torna a tarefa de verificar o enfraquecimento ou fortalecimento da medida bastante complexa -, o fato é que a cada dia tem-se notícias de novos municípios aderindo à restrição.

Apenas a título de ilustração, no ano de 2014, o toque de recolher para crianças e adolescentes foi estabelecido, por meio de portaria judicial, no município de Graça $(\mathrm{CE})^{10}$. Em 2015, a medida foi instituída pelo Poder Judiciário no município de Araucária $(\mathrm{PR})^{11}$. E, em 2016, foi inaugurado, também por iniciativa judicial, nas cidades de Cícero Dantas (BA) ${ }^{12}$ e Antas (BA) ${ }^{13}$.

Destaque-se que, recentemente, alguns municípios implementaram - ou estudam implementar - o toque de recolher através de leis municipais. A restrição, nestes moldes, também tem sido alvo de polêmicas, como no caso do município de Guarapari (ES), que aprovou em 2014 uma legislação sobre o assunto, que ficou conhecida como a "Lei do Menor"14. O projeto de lei havia sido aprovado na Câmara dos Vereadores, sendo em seguida vetado pelo prefeito da cidade. Posteriormente, o veto foi derrubado pelos vereadores, e a lei foi publicada no Diário Oficial e começou a vigorar em março de $2014^{15}$. Em seguida, a Prefeitura de Guarapari questionou no Tribunal de Justiça a constitucionalidade da Lei Municipa ${ }^{16}$.

Anteriormente, em 2009, um vereador de Blumenau (SC) já havia apresen-

\footnotetext{
${ }^{10}$ O POVO. Juiz determina "toque de recolher" para crianças e adolescentes em Graça. $30 \mathrm{abr}$. 2014. Disponível em: <http://www.opovo.com.br/app/fortaleza/2014/04/30/noticiafortaleza,3243955/juiz-determina-toque-de-recolher-para-criancas-e-adolescentes-em-graca.shtml> . Acesso em: 05 jan. 2017.

${ }^{11}$ O POPULAR DO PARANÁ. Araucária agora tem "toque de recolher" para menores. 23 out. 2015. Disponível em: < http://www.opopularpr.com.br/geral/araucaria-agora-tem-toque-de-recolher-para-menores/> . Acesso em: 05 jan. 2017.

${ }^{12}$ CORREIO DA CIDADE. Juiz implanta toque de acolher em Cícero Dantas, na Bahia. 16 nov. 2016. Disponível em: <http://www.correiodacidade.com.br/noticia/12951/juiz-implanta-toque-de-acolher-em-c-cero-dantas-na-bahia >. Acesso em: 05 jan. 2017.

${ }^{13}$ BAHIA NOTÍCIAS. Antas: Juiz implanta "hora de acolher" que restringe permanência de menores nas ruas. 04 nov. 2016. Disponível em: < http://www.bahianoticias.com.br/justica/noticia/55521-antas-juiz-implanta-039hora-de-acolher039-que-restringe-permanencia-de-menores-nas-ruas.html $>$. Acesso em: 05 jan. 2017.

${ }^{14}$ Trata-se da Lei Municipal no 3.729, de 12 de março de 2014.

${ }^{15} \mathrm{G} 1$. Toque de recolher a menores de 16 anos gera polêmica no ES. $01 \mathrm{abr}$. 2014. Disponível em: < http:// g1.globo.com/espirito-santo/noticia/2014/04/toque-de-recolher-menores-de-16-anos-gera-polemica-no-es. html>. Acesso em: 06 jan. 2017.

${ }^{16}$ G1. Prefeitura protocola ação contra "toque de recolher" em Guarapari. 02. abr. 2014. Disponível em: $<$ http://g1.globo.com/espirito-santo/noticia/2014/04/prefeitura-protocola-acao-contra-toque-de-recolher-em-guarapari.html>. Acesso em: 06 jan. 2017.
} 
tado o Projeto de Lei $\mathrm{n}^{0} 5.745$, que objetivava autorizar os Conselhos Tutelares a realizarem o toque de recolher para crianças e adolescentes na cidade. $\mathrm{O}$ argumento utilizado pelo vereador era o de que a medida "pretendia proteger o jovem, uma vez que, se este ficasse na rua, estaria correndo risco de ser desviado para o 'mau caminho' e que o projeto pretendia, assim, proteger 'a família e as pessoas de bem"'17.

Ainda acerca das iniciativas de lei relacionadas com o toque de recolher para crianças e adolescentes, ressalte-se o Projeto de Lei 4.590/2012, que está tramitando na Câmara dos Deputados. O Projeto - de autoria do Deputado Roberto de Lucena (PV/SP) - sugere a inclusão do art. 16-A no Estatuto da Criança e do Adolescente (ECA), com o seguinte teor:

Art. 16-A. O juiz da Vara da Infância e da Juventude, justificadamente, poderá restringir a permanência de crianças e adolescentes em lanchonetes, bares, restaurantes, ou qualquer local público, após as vinte e duas horas, desacompanhados dos genitores ou responsáveis ${ }^{18}$.

Em sua justificativa, o Deputado argumenta que "o direito à liberdade não pode ser confundido com direito ao perdimento da infância e da adolescência”, já que "crianças e adolescentes têm sido empregados para o cometimento dos mais variados tipos de delitos a mando de pessoas maiores de idade". Acrescenta, ainda, que a medida já foi adotada por juízes em várias cidades brasileiras "como forma de reduzir a violência entre jovens". Ele cita, inclusive, o exemplo de Fernandópolis - onde "os atos infracionais de jovens despencaram, houve mudança geral de comportamento" - para fundamentar seu ponto de vista. Ele finaliza argumentando que a medida "é de toda valiosa e merece ser implantada para que as cifras da delinquência juvenil e da vitimização de crianças e adolescentes sejam assaz diminuídas"19.

\footnotetext{
${ }^{17}$ MARCHI, Rita de Cássia; SOUZA, Josué de. O "Toque de recolher" como um retrocesso ao autoritarismo: caminhos e tendências políticas do Conselho Tutelar em Blumenau. Emancipação, Ponta Grossa, v. 12, n. 1, 2012, p. 96. Disponível em: < http://www.revistas2.uepg.br/index.php/emancipacao/article/view/1805/3128> . Acesso em: 25 jun. 2018.

${ }^{18}$ BRASIL. Congresso Nacional. Câmara dos Deputados. Projeto de Lei 4.590/2012. Dispõe sobre a permanência de crianças e adolescentes após as vinte e duas horas, nos locais que especifica. Brasília, 23 out. 2012. Disponível em: < http://www.camara.gov.br/proposicoesWeb/prop_mostrarintegra;jsessionid=104E577BEDE0D9A0F8EC37506789AC51. proposicoesWebExterno1? codteor $=1032716 \&$ filename $=\mathrm{PL}+4590 / 2012>$. Acesso em: 06 jan. 2017.

19 BRASIL. Congresso Nacional. Câmara dos Deputados. Projeto de Lei 4.590/2012. Dispõe sobre a permanência de crianças e adolescentes após as vinte e duas horas, nos locais que especifica. Brasília, 23 out. 2012. Disponível em: <http://www.camara.gov.br/proposicoesWeb/prop_mostrarintegra;jsessionid=104E577BEDE0D9A0F8EC37506789AC51. proposicoesWebExterno1? codteor $=1032716 \&$ filename $=$ PL $+4590 / 2012>$. Acesso em: 06 jan. 2017.
} 
O Projeto de Lei foi remetido à Comissão de Seguridade Social e Família (CSSF) que, em novembro de 2016, emitiu um parecer pela aprovação do Projeto. De acordo com a relatora designada, Deputada Zenaide Maia (PR-RN),

Dar ao juiz da infância e adolescência o poder de, justificadamente, impedir a permanência em locais não condizentes com a pessoa em desenvolvimento, mormente após as vinte e duas horas, quando, como já dissemos, deveriam estar dormindo, é algo que se nos afigura extremamente valioso. Com isto, impediríamos também a exploração sexual dos jovens. Assim, a sugestão apresentada merece ser aprovada, por ser conveniente e oportuna ${ }^{20}$.

Observa-se, portanto, que a problemática continua bastante atual, já que constantemente são publicadas notícias de novos municípios adotando o toque de recolher através de portarias judiciais. Ademais, as recentes propostas de legislação sobre o assunto - tanto em âmbito municipal quanto em âmbito federal - deixam evidente que a polêmica está longe de ser encerrada.

\section{OS ARGUMENTOS DOS MAGISTRADOS}

Os juízes que estabelecem o toque de recolher argumentam que tal medida é necessária para afastar os jovens das drogas e de outros perigos a que estes estão sujeitos nas ruas. Defendem, ainda, que esta restrição é importante para possibilitar um maior convívio das crianças e adolescentes com as suas famílias e para permitir que os mesmos possam desfrutar de mais horas de sono, o que melhoraria o aproveitamento escolar dos jovens.

É possível visualizar estas preocupações na decisão do Juiz de Direito da Vara da Infância e Juventude da Comarca de Ilha Solteira (SP) sobre o toque de recolher. O magistrado justifica da seguinte forma a necessidade de estabelecimento da medida: "o rendimento escolar, o contato com a família, com a consequente ampliação dos laços afetivos, a situação de risco em estar nas ruas em altas horas da noite,

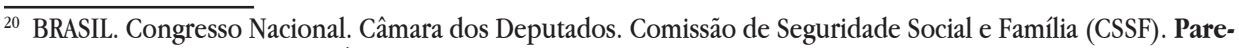
cer sobre o Projeto de Lei 4.590/2012. Dispõe sobre a permanência de crianças e adolescentes após as vinte e duas horas, nos locais que especifica. Brasília, 29 nov. 2016. Disponível em: < http://www.camara.gov.br/ proposicoesWeb/prop_mostrarintegra?codteor $=1511467 \&$ filename $=$ Tramitacao-PL $+4590 / 2012>$. Acesso em: 06 jan. 2017. 
tudo isso aponta para a necessidade de impor limites aos jovens"21.

O Juiz da $1^{\text {a }}$ Vara Criminal e Anexo da Infância e da Juventude da Comarca de Fernandópolis (SP) também utiliza a ideia de situação de risco em sua justificativa para a implantação do toque de recolher. A Portaria 3/2009 estaria sendo baixada, segundo o magistrado, dentre outros motivos,

[...] Considerando a constância ainda presente de denúncias formais e informais sobre situações de risco de crianças e adolescentes pelas cidades da comarca, especificamente, daqueles que permanecem nas ruas durante a noite e madrugada, desacompanhados dos pais ou responsável, expostos, entre outros, ao oferecimento de drogas ilícitas, prostituição e vandalismos (grifo no original) ${ }^{22}$.

As justificativas legais utilizadas pelos juízes que atuam na área da infância e juventude para o estabelecimento do toque de recolher são retiradas do próprio Estatuto da Criança e do Adolescente (ECA).

Para exemplificar o raciocínio empreendido pelos magistrados no processo de caracterização jurídica do toque de recolher, serão utilizadas aqui algumas passagens de uma entrevista realizada em 2010 com um juiz responsável pelo estabelecimento da restrição em sua comarca ${ }^{23}$.

Inicialmente, foi perguntado ao juiz sobre a natureza jurídica do toque de recolher, e se o mesmo poderia ser considerado uma medida protetiva. De acordo com o magistrado,

Sim. Porque na verdade ele tem duplo aspecto, né, jurídico, né. Bom, em primeiro lugar, também: em lugar nenhum, nas nossas decisões, em cinco anos - porque foi mais de uma decisão nesse sentido... -, em nenhum lugar está escrito toque de recolher. Só para deixar bem claro, né. Aliás, não tem nome. Do ponto de vista jurídico, não tem nome. Não tem nomemiuris

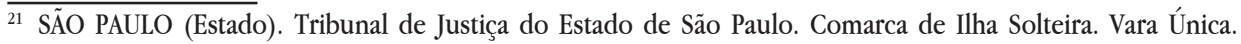
Portaria do Juiz de Direito. Sobre a limitação de horários de circulação de crianças e adolescentes na Comarca. Ilha Solteira, 2009c. Disponível em: < http://www.ilhasolteira.sp.gov.br/documentos/toque_de_recolher. pdf > . Acesso em: 10 dez. 2009.

22 SÃO PAULO (Estado). Tribunal de Justiça do Estado de São Paulo. Comarca de Fernandópolis. $1^{\text {a }}$ Vara Criminal e Anexo da Infância e da Juventude. Portaria 3/2009. Fernandópolis, 23 mar. 2009b, p. 1.

${ }^{23}$ A entrevista foi realizada no dia 02 de setembro de 2010 . Optou-se aqui pela manutenção do anonimato do entrevistado. Cf. ALMEIDA, Fernanda Andrade. O juiz "bicho-papão" e a "lei em movimento": um caso de judicialização à brasileira. Niterói: UFF, 2013. Tese de Doutorado - Programa de Pós-Graduação em Sociologia e Direito, Universidade Federal Fluminense. 
para decisão do juiz. Não existe isso. [...] Quer dizer, nós recebemos esse apelido, né... E aí eu fiquei muito preocupado no começo, eu briguei, eu não gostei, eu tentei mudar, mas não tinha jeito: era toque de recolher, toque de recolher... Eu falei: "quer saber de uma coisa, eu não me importo com o nome, eu quero saber da essência”. Nós que fazemos direito nós sabemos disso, também o que importa não é o nome das coisas, é a essência, a natureza jurídica. Então quer saber de uma coisa? Falem o que quiser, chamem de toque, chamem de não sei o quê que tem [...] O importante é saber se é a lei que funciona. Então, qual que é a natureza jurídica dessa decisão apelidada de toque de recolher? Ela tem duplo aspecto. Por quê? Porque o Estatuto da Criança e do Adolescente, se você for fazer uma divisão nele, não por artigos, não por aquela divisão, é... de capítulos e seções, mas uma divisão organizacional da proteção integral, você vai ver o seguinte, que tem uma parte que é do adolescente em conflito com a lei, que a gente chama do adolescente infrator, né, que é o adolescente que comete um fato definido como crime. Essa parte é bem clara no Estatuto, onde prevê os procedimentos, medidas socioeducativas etc. Só que essa parte ela é um [...] até numericamente, por artigos, ela deve chegar a um terço do Estatuto. Dois terços do Estatuto estão na prevenção e na proteção. Na primeira parte, um terço, que é a do adolescente em conflito com a lei - acho que não dá nem um terço, dá menos - ali, necessariamente, a lei só se movimenta com iniciativa do Ministério Público, porque cabe a ele a representação do adolescente em conflito com a lei. Então, ali o juiz não age de ofício. Mas nos dois terços do Estatuto, que é a prevenção e a proteção, o juiz age de ofício, sem provocação. Não precisa de provocação nem do Conselho Tutelar, nem do promotor, nem do advogado, por causa do art. 153 , do ECA, que diz que o juiz pode instaurar de ofício o inquérito para apurar qualquer situação naquela lei e tomar providências, né, quer dizer, de ofício, então ele não precisa esperar. Bom, então o quê que é essa decisão conhecida como toque de recolher? Quando nós determinamos que a Polícia vá à rua e aborde o adolescente em risco e leve para o Conselho Tutelar e ali chame o pai e entregue para a mãe o quê que nós estamos fazendo? Olha, locais de risco que têm drogas: direito do adolescente não estar ali: art. 19. Expresso, expresso, né? Art. 98, né: "Todo direito que se encontrar violado ou ameaçado tem que aplicar a medida de proteção". Quais que são as medidas de proteção? Do art. 101: "encaminhamento aos pais ou responsáveis, encaminhamento depois para recuperação" [...] Então nós só [...] Quando a gente fala em medida de proteção, a gente não apenas manda para o pai ou mãe [...] Nós já mandamos o adolescente direto para tratamento de dependência química. São todas aquelas medidas previstas em lei, né[...]. Então, então qual que é o aspecto da medida nesse ponto? Está claro que é proteção, proteção. Até porque 
a medida é protetiva, né. Agora, qual que é o aspecto da prevenção? $O$ aspecto da prevenção, que aí entra na discussão mais é $[. .$.$] polêmica, vamos dizer assim, que se criou em torno$ da decisão, que é assim: essa decisão fere o direito de ir e vir, né, quando nós recomendamos horário - presta atenção no termo, quando nós determinamos à Polícia que vá as ruas em determinado horário. As pessoas não sacaram isso até agora, eu acho $[. .$.$] poucos sacaram isso [...] que nós não criamos lei$ geral para ninguém [...]. Ao contrário, nós estamos aplicando a lei. Quer dizer, há uma manha aí, né, que me parece que as pessoas não se atentaram pra isso (informação verbal) ${ }^{24}$.

Alguns aspectos merecem ser destacados na passagem apresentada. Em primeiro lugar, ressalte-se a observação do magistrado acerca da denominação da medida, e a rejeição da expressão "toque de recolher". É interessante notar que em diversas manifestações - oficiais ou não - de juízes partidários da limitação de horário para crianças e adolescentes, a expressão "toque de recolher" é substituída pela expressão "toque de acolher" ${ }^{25}$. Esta segunda denominação, além de ser menos depreciativa que a primeira, contribui para ressaltar o aspecto da proteção que os magistrados querem sublinhar como caracterizadora da medida, e por isso acabou sendo adotada por muitos deles.

Outro elemento que pode ser destacado na passagem da entrevista transcrita acima é a afirmação do magistrado no sentido de que ele não está criando lei geral. Esse aspecto é fundamental na argumentação dos defensores do toque de recolher, tendo em vista que uma das críticas feitas ao estabelecimento da limitação seria que a medida fere o $\S 2^{\circ}$ do artigo 149 do Estatuto da Criança e do Adolescente, que diz o seguinte: "Art. 149. Compete à autoridade judiciária disciplinar, através de portaria, ou autorizar, mediante alvará: [...] $\S 2^{\circ}$ As medidas adotadas na conformidade deste artigo deverão ser fundamentadas, caso a caso, vedadas as determinações

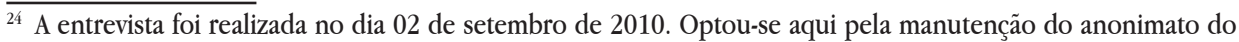
entrevistado. Cf. ALMEIDA, Fernanda Andrade. O juiz "bicho-papão" e a "lei em movimento": um caso de judicialização à brasileira. Niterói: UFF, 2013. Tese de Doutorado - Programa de Pós-Graduação em Sociologia e Direito, Universidade Federal Fluminense.

${ }^{25}$ Neste sentido, ver, por exemplo: NETTO, José Brandão. 78 cidades já possuem o "toque de acolher" ou recolher. Justiça Atuante (Blog), Itapicuru (BA), 06 jun. 2011. Disponivel em: < http://toquedeacolherbahia. blogspot.com.br/2011/06/78-cidades-ja-possuem-o-de-acolher-ou.html > . Acesso em: 8 dez. 2011. SÃO PAULO (Estado). Tribunal de Justiça do Estado de São Paulo. Comarca de Fernandópolis. $1^{\text {a }}$ Vara Criminal e Anexo da Infância e da Juventude. Informações do magistrado nos autos do PCA 2009.10.00.003736-7. Fernandópolis, 18 set. 2009a.
} 


\section{de caráter geral" 26 .}

Na sequência da entrevista supramencionada, o juiz explica que a medida não é apenas protetiva, mas também preventiva. Ele exemplifica a ideia de prevenção presente nas normas do ECA, deixando evidente que a decisão acerca do toque de recolher não é a única forma de prevenção presente no Estatuto, e nem a única limitação ao direito de ir e vir de crianças e adolescentes.

Bom, na parte de prevenção, que o Código prevê de prevenção, como é que a decisão se estrutura. Olha, o art. 16 do Estatuto diz [lendo o ECA]: "é direito da criança e do adolescente ir e vir e estar, inclusive em logradouros públicos vírgula, ressalvadas as restrições legais, ponto". Ou seja, o próprio ECA está dizendo: há restrições ao direito de ir e vir das crianças e adolescentes. Quais são essas restrições? O próprio ECA traz aqui algumas restrições. Uma que nos chama muita atenção é a do 75 , parágrafo único, que diz assim [lendo o $\mathrm{ECA}$ ]: "crianças menores de dez anos"... a primeira idade do ECA não é nem doze, é dez... [continuando a leitura do ECA] "crianças menores de dez anos somente poderão ingressar e permanecer nos locais de apresentação ou exibição quando acompanhadas dos pais ou responsáveis". O caput fala [lendo o ECA]: "toda criança ou adolescente terá direito ao acesso às diversões ou espetáculos públicos classificados como adequados à sua faixa etária". Lendo o artigo conjugado, nós temos o seguinte: nós temos que o menor de dez anos, pelo Estatuto, art. 75, não pode ficar em local público, e não é local de risco público não [...] Não pode ficar em nenhum local público sem o pai e a mãe. É uma interpretação quase que literal do artigo. Imaginemos, igual tem aqui, em uma cidade pequena: 10 horas da manhã, pula-pula na praça, com segurança do Município etc. Pode uma criança de menos de dez anos estar ali? E não estou falando em risco, hein! Não tem nem risco aí para a criança. Pode ficar ali no pula-pula sem o pai ou a mãe? Pelo 75, literalmente, não. Menor de dez anos nem em local público pode estar, né. Somente se tiver com o pai ou responsável. Mas tem mais restrição. Não é? Não é só essa. Tem... Há outras restrições aqui no Estatuto (informação verbal) ${ }^{27}$.

${ }^{26}$ BRASIL. Estatuto da Criança e do Adolescente. Lei no 8.069, de 13 de julho de 1990. Dispõe sobre o Estatuto da Criança e do Adolescente e dá outras providências. Diário Oficial [da] República Federativa do Brasil, Brasília, p. 13563, 16 jul. 1990. Disponível em: < http://www.planalto.gov.br/ccivil_03/leis/18069.htm> . Acesso em: 24 nov. 2012.

${ }^{27}$ A entrevista foi realizada no dia 02 de setembro de 2010. Optou-se aqui pela manutenção do anonimato do entrevistado. Cf. ALMEIDA, Fernanda Andrade. O juiz "bicho-papão" e a "lei em movimento": um caso de judicialização à brasileira. Niterói: UFF, 2013. Tese de Doutorado - Programa de Pós-Graduação em Sociologia e Direito, Universidade Federal Fluminense. 
Em seguida, o magistrado aponta outras restrições presentes no Estatuto da Criança e do Adolescente, como o art. 82 - que proíbe a hospedagem de criança ou adolescente em hotel, salvo se autorizado ou acompanhado pelos pais ou responsáveis - e o art. 86, que diz que nenhuma criança poderá viajar para fora da comarca onde reside desacompanhada dos pais ou responsável, salvo se tiver autorização judicial. Ele completa o raciocínio explicando que os artigos 72 e 149 do Estatuto permitiriam outras restrições, além daquelas que estão expressas.

Cadê o direito de ir e vir? Para coisa boa! Nós não estamos falando de risco, gente. Olha, presta atenção, né! Agora, além dessas restrições, expressas ao direito de ir e vir, que fazem, que conjugam lá com aquela restrição que está no artigo 16 que nós lemos, né, o artigo 72 diz assim, no capítulo da prevenção [lendo o ECA]: "as obrigações previstas nesta lei não excluem da prevenção especial outras decorrentes do princípio por ela adotados". Uma cláusula aberta. Ou seja, a autoridade prevista nessa lei pode estabelecer outras regras de prevenção. E sabe o que a lei faz? Vai lá no art. 149 e a lei fala assim, expressamente [lendo o ECA]: "compete à autoridade judiciária disciplinar, através de portaria, ou autorizar, mediante alvará a entrada e permanência de criança..." E aí começa, tem vários locais [...] Prevenção, tá prevenindo: "Não, ali vai ter bebida alcoólica, vai terminar às 5 horas da manhã, não é o local adequado para menor de 18 anos [...]" O juiz fala: "Nego o alvará. Não entra desacompanhado", né. Então, se o juiz, como nós fizemos aqui, recomenda: "senhores pais, não deixem seus filhos nas ruas, principalmente depois das 23 horas". É um horário escolhido por quê? Para dar uma referência didática também, né, na comunicação que se faz com a sociedade, do Estado com a sociedade. O quê que nós estamos fazendo? Prevenindo. Porque ele vai ficar num local onde tem risco. Onde tem risco, onde tem drogas, onde tem bebida, altas horas da noite [...] Então, qual que é o conteúdo jurídico da decisão, pra resumir? É uma medida de dupla face: proteção e prevenção (informação verbal) ${ }^{28}$.

Destaque-se que um dos principais argumentos dos opositores do toque de recolher é no sentido de que a limitação do horário de circulação de crianças

\footnotetext{
${ }^{28}$ A entrevista foi realizada no dia 02 de setembro de 2010 . Optou-se aqui pela manutenção do anonimato do entrevistado. Cf. ALMEIDA, Fernanda Andrade. O juiz "bicho-papão" e a "lei em movimento": um caso de judicialização à brasileira. Niterói: UFF, 2013. Tese de Doutorado - Programa de Pós-Graduação em Sociologia e Direito, Universidade Federal Fluminense.
} 
e adolescentes configuraria um desrespeito ao direito de ir e vir dos mesmos. Em razão disso, o entrevistado desenvolve uma argumentação demonstrando que diversas restrições ao direito de ir e vir estão presentes no ECA. Assim, ele procura deixar claro que o toque de recolher não é algo excepcional, pois caracteriza-se como uma medida preventiva, tal como outras medidas presentes em vários artigos do Estatuto.

Em síntese, durante a sua fala, o magistrado entrevistado utiliza diversos dispositivos do Estatuto da Criança e do Adolescente para conferir juridicidade ao toque de recolher. Inicialmente, ele explica que o artigo 16, I do ECA - que fala sobre o direito de ir e vir das crianças e adolescentes - é finalizado com uma indicação de "ressalvadas as restrições legais". Em seguida, o entrevistado aponta as várias restrições presentes na Lei no 8.069/1990. A argumentação fica completa quando ele menciona os artigos 72 e 149 do Estatuto que, conjugados, permitiriam que a autoridade judiciária estabelecesse outras restrições não expressas na Lei.

Em um documento elaborado pelo Juiz de Direito da Comarca de Fernandópolis - que consistia em informações que seriam apresentadas pelo magistrado ao CNJ, nos autos do Procedimento de Controle Administrativo que discutia a questão do toque de recolher na comarca - também notamos a preocupação em refutar a afirmação de que o toque de recolher contrariaria o $§ 2^{\circ}$ do art. 149 . Após explicar que o conteúdo da decisão judicial estabelecida na Portaria 03/2009 - que implementa a limitação na Comarca - consiste na determinação de que as Polícias (Civil e Militar) e o Conselho Tutelar devem "recolher crianças e adolescentes - desacompanhados dos pais ou de adulto responsável - em situações de risco [...], encaminhando-os aos pais, imediatamente, como medida de proteção, mediante advertência"29, o magistrado explica:

Não há conteúdo algum de norma geral e abstrata, dirigida a pessoas indeterminadas, com determinaçóes de caráter geral, horários etc., para que se faça ou se deixe de fazer algo (algum comportamento), de modo a ferir o disposto no art. 149, $\$ 2 .^{\circ}$, do Estatuto da Criança e do Adolescente (ECA). A ordem é destinada, formal e especificamente, às autoridades policiais e ao Conselho Tutelar, a partir do princípio estatutário fundamental da proteção integral (grifo no original) ${ }^{30}$.

$\overline{29}$ SÃO PAULO (Estado). Tribunal de Justiça do Estado de São Paulo. Comarca de Fernandópolis. $1^{\text {a }}$ Vara Criminal e Anexo da Infância e da Juventude. Informaçóes do magistrado nos autos do PCA 2009.10.00.003736-7. Fernandópolis, 18 set. 2009a, p. 13.

${ }^{30}$ SÃO PAULO (Estado). Tribunal de Justiça do Estado de São Paulo. Comarca de Fernandópolis. $1^{\text {a }}$ Vara Criminal e Anexo da Infância e da Juventude. Informações do magistrado nos autos do PCA 2009.10.00.003736-7. Fernandópolis, 18 set. 2009a, p. 13. 
Pode-se concluir - a partir da análise de documentos jurídicos oficiais produzidos por magistrados, bem como de elementos presentes na narrativa do juiz entrevistado na pesquisa - que os discursos produzidos pelos magistrados que estabeleceram o toque de recolher em suas comarcas oscilam entre uma justificativa técnica - provar que a medida está de acordo com a lei e, mais especificamente, com o Estatuto da Criança e do Adolescente - e uma justificativa fática para a restrição. Neste último caso, o ponto principal da argumentação reside em apresentar os problemas existentes na cidade envolvendo os jovens - drogas, prostituição etc. -, bem como os benefícios - por exemplo, diminuição dos atos infracionais - que podem surgir com a imposição da medida na comarca.

\section{OS PODERES DO JUIZ NO ÂMBITO DO DIREITO DA CRIANÇA E DO ADO- LESCENTE: COMPARAÇÃO ENTRE O ECA E O CÓDIGO DE MENORES DE 1979}

O toque de recolher suscita variados debates, dentre os quais a discussão acerca dos limites da atuação do Juiz da Vara da Infância e Juventude. Nesse sentido, é relevante o estabelecimento de uma comparação entre o revogado Código de Menores e o Estatuto da Criança e do Adolescente, no que se refere a esta questão.

A Lei $\mathrm{n}^{0}$ 6.697, de 10 de outubro de 1979, que instituiu o Código de Menores, era direcionada aos jovens em "situação irregular". Isso fica evidente logo no início do diploma legal:

Art. $1^{\circ}$ Este Código dispõe sobre assistência, proteção e vigilância a menores: I - até dezoito anos de idade, que se encontrem em situação irregular; II - entre dezoito e vinte e um anos, nos casos expressos em lei. Parágrafo único - As medidas de caráter preventivo aplicam-se a todo menor de dezoito anos, independentemente de sua situação. Art. $2^{\circ}$ Para os efeitos deste Código, considera-se em situação irregular o menor: I - privado de condições essenciais à sua subsistência, saúde e instrução obrigatória, ainda que eventualmente, em razão de: a) falta, ação ou omissão dos pais ou responsável; b) manifesta impossibilidade dos pais ou responsável para provê-las; Il - vítima de maus tratos ou castigos imoderados impostos pelos pais ou responsável; III - em perigo moral, devido a: a) encontrar-se, de modo habitual, em ambiente contrário aos bons costumes; b) exploração em atividade contrária aos bons 
costumes; IV - privado de representação ou assistência legal, pela falta eventual dos pais ou responsável; V - Com desvio de conduta, em virtude de grave inadaptação familiar ou comunitária; VI - autor de infração penal. Parágrafo único. Entende-se por responsável aquele que, não sendo pai ou mãe, exerce, a qualquer título, vigilância, direção ou educação de menor, ou voluntariamente o traz em seu poder ou companhia, independentemente de ato judicial ${ }^{31}$.

Estes dois artigos permitem inferir que o Código de Menores fazia nítida distinção entre o "direito do menor" e o "direito da criança". Tal entendimento é corroborado pelo relatório do Parecer da Comissão de Constituição e Justiça da Câmara dos Deputados ao Projeto $\mathrm{n}^{\mathrm{O}} 105 / 74$, do Senador Nelson Carneiro - projeto de lei que deu origem ao Código de Menores e que, na Câmara, tomou o n ${ }^{0} 1.573-\mathrm{A}$, de 1975. No parecer, cuja relatoria coube ao Deputado Claudino Sales, encontramos a seguinte observação sobre os arts. $1^{\circ}$ e $2^{\circ}$ :

A pessoa que constitui o sujeito do Direito do Menor não é qualquer criança, mas o menor em estado de patologia social ampla, pois que a solução do problema em que se encontra será regulada através de uma decisão judicial, emanada de um processo judicial, fiscalizado pelo Ministério Público. As emendas propostas aos arts. $1^{\circ}$ e $2^{\circ}$ do Projeto objetivam estabelecer nítida distinção entre o que se constitui, genericamente, em Direitos da Criança, e o que pertence ao campo específico da tutela jurídica do Direito do Menor. Da Declaração dos Direitos da Criança, aprovada pela ONU, resulta o reconhecimento de que as necessidades básicas de toda criança são aquelas acolhidas pelo Projeto. A projeção prática dessa Declaração é a elaboração e efetivação de programas de atuação, o mais amplo possível, nos quais a preocupação é garantir às populações infantis e jovens as melhores condições de desenvolvimento social e maturação biopsíquica. Já o Direito do Menor - e o Código de Menores como seu instrumento - é restrito a peculiares situações em que se encontrem certas crianças a exigirem a prestação jurisdicional. A emenda propõe que tal situação seja identificada pela expressão "situação irregular" (grifo nosso) $)^{32}$.

${ }_{31}$ BRASIL. Código de Menores. Lei no 6.697, de 10 de outubro de 1979. Institui o Código de Menores. Diário Oficial da União, Brasília, p. 14945, 11 out. 1979a. Disponível em: < http://www.planalto.gov.br/ccivil_03/ leis/1970-1979/L6697impressao.htm > . Acesso em: 24 nov. 2012.

32 SENADO FEDERAL. Subsecretaria de Edições Técnicas. Código de Menores. Lei no 6.697/79, comparações, anotações, histórico, por Ana Valderez A. N. de Alencar e Carlos Alberto de Sousa Lopes. Brasília, Senado Federal, 1982, p. 75. 
Acrescente-se, ainda, que o parágrafo único do art. $1^{\circ}$ não existia no Projeto original do Senador Nelson Carneiro (Projeto $\mathrm{n}^{\mathrm{o}}$ 105/74), tendo sido acrescentado no Substitutivo elaborado pela Comissão Especial instituída no Senado para o estudo da matéria. Na ocasião, o Senador José Lindoso, relator do Projeto na Comissão Especial, explicou que a norma acrescida destacava "a particularidade de distinguirem-se as medidas de assistência e proteção - destinadas a determinados grupos de menores - das medidas de vigilância endereçadas a todos eles, desde que com idade inferior a 18 anos, inclusive àqueles sob o pátrio poder". As "medidas preventivas", explicitadas no parágrafo único do art. $1^{\circ}$, seriam "gênero de que é espécie a medida de vigilância”’33.

Acerca do papel da autoridade judiciária, o Código de Menores estabelecia:

Art. $6^{\circ} \mathrm{A}$ autoridade judiciária a que se refere esta Lei será o Juiz de Menores, ou o Juiz que exerça essa função na forma da legislação local. Art. $7^{\circ}$ À autoridade judiciária competirá exercer diretamente, ou por intermédio de servidor efetivo ou de voluntário credenciado, fiscalização sobre o cumprimento das decisões judiciais ou determinações administrativas que houver tomado com relação à assistência, proteção e vigilância a menores. Parágrafo único. A fiscalização poderá ser desempenhada por comissários voluntários, nomeados pela autoridade judiciária, a título gratuito, dentre pessoas idôneas merecedoras de sua confiança. Art. $8^{\circ} \mathrm{A}$ autoridade judiciária, além das medidas especiais previstas nesta Lei, poderá, através de portaria ou provimento, determinar outras de ordem geral, que, ao seu prudente arbítrio, se demonstrarem necessárias à assistência, proteção e vigilância ao menor, respondendo por abuso ou desvio de poder (grifo nosso) ${ }^{34}$.

O Relator do Projeto de Lei n ${ }^{\circ}$ 1.573-A, na Câmara dos Deputados, enfatizou a importância da norma contida no art. $8^{\circ}$ pelo fato dela "conferir ao Juiz poderes para disciplinar situações emergentes" ${ }^{\prime 3}$.

33 SENADO FEDERAL. Subsecretaria de Edições Técnicas. Código de Menores. Lei no 6.697/79, comparações, anotações, histórico, por Ana Valderez A. N. de Alencar e Carlos Alberto de Sousa Lopes. Brasília, Senado Federal, 1982, p. 79.

${ }^{34}$ BRASIL. Código de Menores. Lei no 6.697, de 10 de outubro de 1979. Institui o Código de Menores. Diário Oficial da União, Brasília, p. 14945, 11 out. 1979a. Disponível em: < http://www.planalto.gov.br/ccivil_03/ leis/1970-1979/L6697impressao.htm > . Acesso em: 24 nov. 2012.

35 SENADO FEDERAL. Subsecretaria de Edições Técnicas. Código de Menores. Lei no 6.697/79, comparações, anotações, histórico, por Ana Valderez A. N. de Alencar e Carlos Alberto de Sousa Lopes. Brasília, Senado Federal, 1982, p. 113. 
Observe-se que norma semelhante era encontrada no art. $1^{\circ}$ do Esboço do Código de Menores, apresentado pelo Juiz de Menores do então Estado da Guanabara - Alberto Augusto Cavalcanti de Gusmão - no III Encontro Nacional de Juízes de Menores, realizado em Brasília de 7 a 21 de outubro de 1968. Dizia o mencionado art. $1^{\circ}$ que: "A autoridade judicial competente poderá, entretanto, emitir, para a proteção de menores, mesmo não abandonados, qualquer provimento geral que, ao seu prudente arbítrio, parecer conveniente, ficando sujeita à responsabilidade por abuso de poder" 36 .

$\mathrm{Na}$ ocasião, o magistrado apresentou a seguinte justificativa para a inclusão da norma em um Código de Menores:

Esta regra é de uma importância extraordinária e tem se revelado no Brasil de grande utilidade. Já se tem feito ver que o Juiz de Menores no Brasil é talvez o único em todo o mundo, armado desses poderes normativos. Creio não exagerar dizendo que esta norma tem permitido aos juízes brasileiros efetuarem um trabalho de prevenção que, talvez, não seja possível em outras partes do mundo. De grande valia tem sido para os nossos costumes a utilização desse dispositivo (grifo nosso) ${ }^{37}$.

Nos comentários ao art. $8^{\circ}$ do Código de Menores contemporâneos ao diploma normativo existe divergência de opinião acerca dos poderes conferidos ao Juiz de Menores. Em documentos da época - jornais, pareceres de Deputados e Senadores, manifestações de juristas - encontram-se tanto opiniões contrárias à concessão de poderes excessivos aos juízes de menores quanto opiniões favoráveis ${ }^{38}$.

Destaque-se, ainda, que o art. $8^{\circ}$ do Código de Menores de 1979 encontra correspondência no Código dos Menores de 1927 (Decreto n ${ }^{0}$ 17.943-A, de 12 de outubro de 1927). Também conhecido como Código Mello Mattos, a legislação visava consolidar as leis de assistência e proteção a menores. Seu art. 131 trazia a regra de que "a autoridade protetora dos menores pode emitir para a proteção e assistên-

\footnotetext{
${ }^{36}$ SENADO FEDERAL. Subsecretaria de Edições Técnicas. Código de Menores. Lei n ${ }^{0}$ 6.697/79, comparações, anotações, histórico, por Ana Valderez A. N. de Alencar e Carlos Alberto de Sousa Lopes. Brasília, Senado Federal, 1982, p. 113.

${ }^{37}$ SENADO FEDERAL. Subsecretaria de Edições Técnicas. Código de Menores. Lei no 6.697/79, comparações, anotações, histórico, por Ana Valderez A. N. de Alencar e Carlos Alberto de Sousa Lopes. Brasília, Senado Federal, 1982, p. 113.

${ }^{38}$ SENADO FEDERAL. Subsecretaria de Edições Técnicas. Código de Menores. Lei no 6.697/79, comparações, anotações, histórico, por Ana Valderez A. N. de Alencar e Carlos Alberto de Sousa Lopes. Brasília, Senado Federal, 1982.
} 
cia destes qualquer provimento que, ao seu prudente arbítrio, parecer conveniente, ficando sujeita à responsabilidade pelos abusos de poder"39.

No Título V, o Código de Menores de 1979 tratava "das medidas de assistência e proteção". Este título se subdividia em 6 capítulos. No capítulo IV, que compreendia os artigos 48 a 58, a lei tratava "das medidas de vigilância". O referido capítulo enumerava diversas limitações para menores, em relação a casas de jogos, hotéis, espetáculos teatrais, cinematográficos, circenses, radiofônicos etc. Tais estabelecimentos, de acordo com o art. 48 do Código, poderiam ser inspecionados, a qualquer tempo, pela autoridade judiciária competente e pelo Ministério Público ${ }^{40}$.

Existia na época uma discussão sobre a constitucionalidade do art. 52, tendo em vista que tal norma - que estava dentro da Seção II (Das Casas de Espetáculos, das Diversões em Geral, dos Hotéis e Congêneres), Subseção I (Dos Espetáculos Teatrais, Cinematográficos, Circenses, Radiofônicos e de Televisão), do referido Capítulo IV - afirmava que "a autoridade judiciária poderá ampliar, dadas as circunstâncias, o limite de idade fixado pelo Serviço Federal de Censura" ${ }^{1}$. Ocorre que, na mesma época, a Constituição Federal afirmava que: "Art. $8^{\circ}$ - Compete à União: [...] VIII organizar e manter a Polícia Federal com a finalidade de: [...] d) prover a censura de diversões públicas; [...]"42.

Assim, havia uma enorme polêmica acerca do fato de o artigo 52 do Código de Menores tratar de matéria definida pela Constituição Federal como sendo de competência da União. Inclusive, o Projeto de Lei ${ }^{\circ} 2.540$, de 1979 - de autoria do Deputado Carlos Chiarellie que visou introduzir alterações na Lei no 6.697/1979 -, em seu art. $4^{0}$, pretendia revogar o disposto no art. 52 do Código de Menores ${ }^{43}$, com a seguinte justificativa:

Propõe-se a revogação pura e simples do art. 52 da Lei $n^{\circ}$

${ }_{39}$ BRASIL. Código dos Menores. Decreto n ${ }^{0}$ 17.943-a de 12 de outubro de 1927. Consolida as leis de assistência e proteção a menores. Coleção das Leis do Brasil, Poder Executivo, Rio de Janeiro, 31 dez. 1927. Disponível em: < http://www.planalto.gov.br/ccivil_03/decreto/1910-1929/D17943Aimpressao.htm>. Acesso em: 24 nov. 2012.

${ }^{40}$ BRASIL. Código de Menores. Lei ${ }^{\circ}$ 6.697, de 10 de outubro de 1979. Institui o Código de Menores. Diário Oficial da União, Brasília, p. 14945, 11 out. 1979a. Disponível em: < http://www.planalto.gov.br/ccivil_03/ leis/1970-1979/L6697impressao.htm > . Acesso em: 24 nov. 2012.

${ }^{41}$ BRASIL. Código de Menores. Lei n ${ }^{\circ}$ 6.697, de 10 de outubro de 1979. Institui o Código de Menores. Diário Oficial da União, Brasília, p. 14945, 11 out. 1979a. Disponível em: < http://www.planalto.gov.br/ccivil_03/ leis/1970-1979/L6697impressao.htm > . Acesso em: 24 nov. 2012.

${ }^{42}$ BRASIL. Emenda Constitucional n ${ }^{\circ} 1$, de 17 de outubro de 1969. Edita o novo texto da Constituição Federal de 24 de janeiro de 1967. Diário Oficial da União, 20 out. 1969. Disponível em: < http://www.planalto.gov. br/ccivil_03/Constituicao/Emendas/Emc_anterior1988/emc01-69.htm> Acesso em: 24 nov. 2012.

${ }^{43}$ Cf. BRASIL. Congresso Nacional. Câmara dos Deputados. Projeto de Lei 2540/1979. Introduz alterações na Lei 6697, de 10 de outubro de 1979 (Código de Menores). Brasília, 04 dez. 1979b. Disponível em: < http:// www.camara.gov.br/proposicoesWeb/fichadetramitacao?idProposicao=204430 > . Acesso em: 24 nov. 2012. 
6.697, de 10-10-1979. Tal dispositivo é, em primeiro lugar, inconstitucional e, em segundo lugar, impraticável. Inconstitucional porque conflita com o art. $8^{\circ}$, inciso VIII, letra d, da Carta Magna, onde se consagra o princípio de que a censura é de competência federal; inviável, porque nos termos do Código de Menores, passaria a ser simultaneamente regulada, em cada comarca, pelo Juiz responsável, distribuindo-se sua decisão entre cerca de dois mil magistrados, cada um com seus critérios próprios e o seu entendimento individual. Como compatibilizar, com tal fracionamento de opinião, as programações nacionais, estaduais ou regionais de rádio e televisão? Como ensejar que todos os Juízes de todas as comarcas vejam antecipadamente, para poder censurar, todos os programas nacionais, estaduais, regionais ou municipais de rádio e televisão? Por isso, a municipalização da censura é impossível na prática, inconstitucional nos cânones jurídicos e contrária à preservação e valorização de padrões culturais de ordem nacional (grifo nosso) ${ }^{44}$.

A regra contida no art. 52 do revogado Código de Menores - que possibilitava que a autoridade judiciária alterasse um limite estabelecido pelo Serviço Federal de Censura -proporciona uma noção da amplitude de poder que o Juiz de Menores possuía naquela época.

Durante a década de 80, ocorreu no Brasil uma pressão dos movimentos sociais pelo reconhecimento dos direitos das crianças e dos adolescentes. Isso resultou no surgimento da Lei 8.069/1990. O ECA trouxe uma grande modificação na legislação sobre o tema, já que o foco deixou de ser a "delinquência" e a "criança abandonada" e passou a ser os direitos das crianças e adolescentes de maneira ampla ${ }^{45}$.

Os pesquisadores da área costumam chamar atenção para uma transição do direito do menor (Doutrina da Situação Irregular) para o direito da criança e do adolescente (Doutrina da Proteção Integral) ${ }^{46}$. Nesse contexto, o ECA substituiu o termo "menor" pelos termos "criança" e "adolescente". Isso porque a primeira

\footnotetext{
$\overline{{ }^{4} 4}$ SENADO FEDERAL. Subsecretaria de Edições Técnicas. Código de Menores. Lei no 6.697/79, comparações, anotações, histórico, por Ana Valderez A. N. de Alencar e Carlos Alberto de Sousa Lopes. Brasília, Senado Federal, 1982, p. 238.

${ }^{45}$ MARINHO, Frederico Couto; VARGAS, Joana Domingues. Permanências e resistências: legislação, gestão e tratamento da delinquência juvenil no Brasil e na França. Dilemas: Revista de Estudos de Conflito e Controle Social, Rio de Janeiro, Edição Especial n. 1, p. 267-298, 2015.

${ }^{46}$ CUSTÓDIO, André Viana. Teoria da Proteção Integral: pressuposto para compreensão do Direito da Criança e do Adolescente. Revista do Programa de Pós-Graduação em Direito - Mestrado e Doutorado da Universidade de Santa Cruz do Sul, Santa Cruz do Sul, n. 29, Jan-Jun/2008, p. 22-43. Disponível em: < http:// online.unisc.br/seer/index.php/direito/article/view/657/454>. Acesso em: 03 nov. 2015.
} 
palavra adquiriu um significado estigmatizante, deixando de significar apenas uma categoria jurídica e transformando-se em um termo que tem conotações negativas, aproximando-se da ideia de delinquência ${ }^{47}$.

A Lei 8.069/1990 transformou as crianças e os adolescentes em sujeitos de direito. Sendo assim, eles deixaram de ser considerados objetos de tutela e controle por parte do Estado, da família e da sociedade. Além dos direitos fundamentais inerentes à pessoa humana, foram atribuídos a eles os direitos decorrentes da condição peculiar de pessoa em desenvolvimento. O ECA trouxe a necessidade de proteção integral e prioritária das pessoas com idade inferior a 18 anos, cabendo a todos família, sociedade e Estado - a responsabilidade pela efetivação dos seus direitos.

Em suma, constata-se uma grande discrepância entre o Código de Menores e a atual Lei $\mathrm{n}^{\circ} 8.069$, de 13 de julho de 1990, que dispõe sobre o Estatuto da Criança e do Adolescente (ECA). A distinção entre criança e menor perde sentido no novo diploma, bem como a noção de "situação irregular", na medida em que a Lei "dispõe sobre a proteção integral à criança e ao adolescente" (art. $1^{\circ}$ ), considerando "criança, para os efeitos desta Lei, a pessoa até doze anos de idade incompletos, e adolescente aquela entre doze e dezoito anos de idade" (art. $\left.2^{\circ}\right)^{48}$.

Assim, o ECA rompeu definitivamente com a doutrina da situação irregular, estabelecendo a doutrina de proteção integral, em coerência com a Constituição de 1988 e os documentos internacionais vigentes à época ${ }^{49}$.

As disposições sobre o juiz são encontradas no Título VI ("Do Acesso à Justiça"), Capítulo II (Da Justiça da Infância e da Juventude), Seção II (Do Juiz), que compreende os artigos 146 a 149. O artigo 146 estabelece que "a autoridade a que se refere esta Lei é o Juiz da Infância e da Juventude, ou o juiz que exerce essa função, na forma da lei de organização judiciária local”"

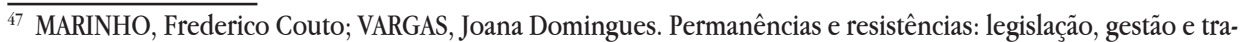
tamento da delinquência juvenil no Brasil e na França. Dilemas: Revista de Estudos de Conflito e Controle Social, Rio de Janeiro, Edição Especial n. 1, p. 267-298, 2015.

${ }^{48}$ BRASIL. Estatuto da Criança e do Adolescente. Lei no 8.069 , de 13 de julho de 1990. Dispõe sobre o Estatuto da Criança e do Adolescente e dá outras providências. Diário Oficial [da] República Federativa do Brasil, Brasília, p. 13563, 16 jul. 1990. Disponível em: < http://www.planalto.gov.br/ccivil_03/leis/18069.htm>. Acesso em: 24 nov. 2012.

${ }^{49}$ CURY, Munir; SILVA, Antônio Fernando do Amaral e; MENDEZ, Emílio García (Coord.). Estatuto da Criança e do Adolescente Comentado. Comentários Jurídicos e Sociais. São Paulo: Malheiros, 1992.

${ }^{50}$ BRASIL. Estatuto da Criança e do Adolescente. Lei no 8.069 , de 13 de julho de 1990. Dispõe sobre o Estatuto da Criança e do Adolescente e dá outras providências. Diário Oficial [da] República Federativa do Brasil, Brasília, p. 13563, 16 jul. 1990. Disponível em: < http://www.planalto.gov.br/ccivil_03/leis/18069.htm>. Acesso em: 24 nov. 2012.
} 
Já o artigo 149 dispõe que:

Art. 149. Compete à autoridade judiciária disciplinar, através de portaria, ou autorizar, mediante alvará: I - a entrada e permanência de criança ou adolescente, desacompanhado dos pais ou responsável, em: a) estádio, ginásio e campo desportivo; b) bailes ou promoções dançantes; c) boate ou congêneres; d) casa que explore comercialmente diversões eletrônicas; e) estúdios cinematográficos, de teatro, rádio e televisão. II - a participação de criança e adolescente em: a) espetáculos públicos e seus ensaios; b) certames de beleza. $\S 1^{\circ}$ Para os fins do disposto neste artigo, a autoridade judiciária levará em conta, dentre outros fatores: a) os princípios desta Lei; b) as peculiaridades locais; c) a existência de instalações adequadas; d) o tipo de frequência habitual ao local; e) a adequação do ambiente a eventual participação ou frequência de crianças e adolescentes; f) a natureza do espetáculo. $\S 2^{\circ}$ As medidas adotadas na conformidade deste artigo deverão ser fundamentadas, caso a caso, vedadas as determinações de caráter geral ${ }^{51}$.

Percebe-se uma alteração muito relevante, no que se refere à amplitude do poder da autoridade judiciária, comparando-se o antigo diploma e o atual. Assim,

[...] não mais se cogita do antigo poder normativo. Houve coerência e juridicidade ao se extinguir o poder normativo do art. $8^{\circ}$ do Código de Menores. Não é do Judiciário ditar normas de caráter geral, mas decidir, no caso concreto, a aplicação do Direito objetivo. Juiz não é legislador, não elabora normas de comportamento social. Julga os comportamentos frente às regras de conduta da vida social. Essas geralmente decorrem do processo legislativo, reservado pela Constituição a outra órbita (grifo nosso) ${ }^{52}$.

A partir desse breve histórico legislativo, ficou evidente que o Estatuto da Criança e do Adolescente conferiu à autoridade judiciária um poder menor do que aquele conferido ao juiz pelas legislações anteriores, de 1979 e de 1927. Todavia, alguns temas da área da infância e juventude - como a questão das portarias judiciais

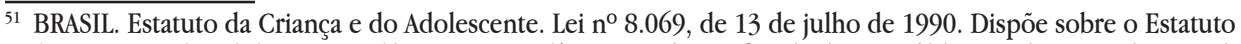
da Criança e do Adolescente e dá outras providências. Diário Oficial [da] República Federativa do Brasil, Brasília, p. 13563, 16 jul. 1990. Disponível em: < http://www.planalto.gov.br/ccivil_03/leis/8069.htm > . Acesso em: 24 nov. 2012.

${ }^{52}$ CURY, Munir; SILVA, Antônio Fernando do Amaral e; MENDEZ, Emílio García (Coord.). Estatuto da Criança e do Adolescente Comentado. Comentários Jurídicos e Sociais. São Paulo: Malheiros, 1992, p. 450. 
do toque de recolher - ainda geram controvérsias no que se refere aos limites da atuação do magistrado.

\section{A NATUREZA JURÍDICA DO TOQUE DE RECOLHER E OS LIMITES DA AUTO- RIDADE JUDICIÁRIA NA ÁREA DA INFÂNCIA E JUVENTUDE}

Na seção 3 foram apresentados os argumentos dos magistrados para o estabelecimento do toque de recolher. Uma das questões apontadas se referia à natureza dessa medida. Observou-se que, para os magistrados defensores da limitação, esta possuiria um caráter protetivo e preventivo. Nesta seção será discutida a natureza jurídica do toque de recolher e os limites da autoridade judiciária na área da infância e juventude.

Como explica Emilio García Méndez, "un análisis histórico riguroso demuestra que la historia de la infancia es la historia de su control". ${ }^{53}$ Sendo assim, compreende-se aqui que alguns apontamentos sobre a história da infância - e, mais especificamente, sobre a história do controle social exercido sobre crianças e adolescentes - podem contribuir para elucidar muitas das dificuldades que ainda aparecem quando se discute acerca das políticas públicas relacionadas com esta parcela da população.

Uma análise histórica do controle social exercido sobre crianças e adolescentes no Brasil no século XIX e início do século XX permite inferir que não havia distinção entre menores abandonados e menores infratores, sendo ambos os grupos considerados "menores de rua", e recebendo o mesmo tratamento, de natureza repressiva e com intervenção policial. Compreender esse período histórico, bem como a lógica de intervenção utilizada neste momento, contribui para uma reflexão sobre os motivos pelos quais ainda hoje se defende que o controle social de crianças e adolescentes deva ser feito de forma repressiva por meio do Estado ${ }^{54}$.

O fim da escravidão, o processo de industrialização e a chegada de imigrantes foram fatores que contribuíram para o crescimento dos principais centros

\footnotetext{
${ }^{53}$ MÉNDEZ, Emilio García. La Convención Internacional de los derechos de la infancia: del menor como objeto de la compasión-represión a la infancia-adolescencia como sujeto de derechos. Nuevo Foro Penal, $\mathrm{n}^{\circ} 57$, Julio, 1992, p. 421.

${ }^{54}$ CAMPELLO, Mauro José do Nascimento. A lógica que se esconde na Portaria "Toque de recolher" baixada pelo Estado-Juiz. Examãpaku. Revista Eletrônica de Ciências Sociais, História e Relações Internacionais (UFRR), v. 5, n. 1, p. 1-22, 2012. Disponível em: < https://revista.ufrr.br/examapaku/article/view/1447>. Acesso em: 25 jun. 2018.
} 
urbanos do país. Isso trouxe como consequência o aumento do número de crianças andando pelas ruas. Tratavam-se de jovens negros, filhos de imigrantes ou filhos de trabalhadores ligados à indústria e ao comércio. Muitas vezes, perambulavam pelas ruas pedindo esmolas ou cometendo pequenos delitos contra o patrimônio ${ }^{55}$.

Os "menores" pobres ou abandonados recebiam a mesma atuação repressiva por parte do Estado que os "menores" infratores, o que gerou uma confusão, que persiste ainda hoje, entre pobreza e delinquência, com a atuação repressora da polícia em ambos os casos. "Logo, o modelo de atendimento aos 'menores' de rua no século XIX, de mentalidade penal, firma as bases de mitos conservadores que nos influenciam até hoje" ${ }^{n 6}$.

Historicamente, pode-se notar a existência de "duas infâncias" na realidade brasileira. Encontram-se, por um lado, aqueles "bem-nascidos", que são as crianças sob os cuidados da família, que têm a infância garantida. Os que não se enquadram nesse grupo, por outro lado, “estão sujeitos à ‘educação' ou 'correção’ pelo aparato repressivo-assistencial do Estado". Ou seja, tratam-se de crianças que não são cidadãs, mas objeto de tutela do Estado ${ }^{57}$.

Como consequência, foram formadas duas categorias dentro da infância: as crianças e os menores. Essa distinção teria sido reforçada, como narra Méndez, pela instituição escolar, que incluiria as crianças e excluiria os menores. Para as primeiras, a escola e a família teriam um papel fundamental na socialização. Para os segundos, houve a necessidade de criação de uma outra esfera de controle social ${ }^{8}$.

Pero la construcción social de la categoría infancia sería imposible de entender sin hacer mención a la institución que

55 CAMPELLO, Mauro José do Nascimento. A lógica que se esconde na Portaria "Toque de recolher" baixada pelo Estado-Juiz. Examãpaku. Revista Eletrônica de Ciências Sociais, História e Relações Internacionais (UFRR), v. 5, n. 1, p. 1-22, 2012. Disponível em: < https://revista.ufrr.br/examapaku/article/view/1447>. Acesso em: 25 jun. 2018.

${ }^{56}$ CAMPELlO, Mauro José do Nascimento. A lógica que se esconde na Portaria "Toque de recolher" baixada pelo Estado-Juiz. Examãpaku. Revista Eletrônica de Ciências Sociais, História e Relações Internacionais (UFRR), v. 5, n. 1, 2012, p. 5. Disponível em: < https://revista.ufrr.br/examapaku/article/view/1447>. Acesso em: 25 jun. 2018.

${ }^{57}$ MARCHI, Rita de Cássia; SOUZA, Josué de. O "Toque de recolher" como um retrocesso ao autoritarismo: caminhos e tendências políticas do Conselho Tutelar em Blumenau. Emancipação, Ponta Grossa, v. 12, n. 1, 2012, p. 91. Disponível em: < http://www.revistas2.uepg.br/index.php/emancipacao/article/view/1805/3128>. Acesso em: 25 jun. 2018.

${ }^{58}$ MÉNDEZ, Emilio García. La Convención Internacional de los derechos de la infancia: del menor como objeto de la compasión-represión a la infancia-adolescencia como sujeto de derechos. Nuevo Foro Penal, $\mathrm{n}^{0}$ 57, p. 421-432, Julio, 1992. 
contribuyó decisivamente a su consolidación y reproducción ampliada: la escuela. Sin embargo, no todos los integrantes de esta nueva categoría tienen acceso a la institución escuela, e incluso, una parte de los que se incorporan, resultan por diversos motivos, expulsados de la misma. La diferencia socio-cultural que se establece en el interior del universo infancia, entre aquellos que permanecen vinculados a la escuela y aquellos que no tienen acceso o son expulsados de ella es tal, que el concepto genérico infancia no podrá abarcarlos. Los excluidos se convertirán en menores. Para la infancia, la familia y la escuela cumplirán las funciones de control y socialización. Para los menores será necesaria la creación de una instancia diferenciada de control socio-penal: el tribunal de menores (que no por acaso recibe desde sus orígenes esta denominación). Ya he hecho referencia en otras oportunidades, a los momentos de creación, reproducción ampliada y finalmente exportación hacia América Latina de esta institución de control específico denominada tribunales de menores [...]. Por otra parte, el análisis específico de este proceso permite afirmar que se trató mucho más de la introducción de una cultura socio-jurídica de la protección-represión, que de una implantación institucional sistemática ${ }^{59}$.

Rita de Cássia Marchi e Josué de Souza, analisando especificamente o caso da proposta de toque de recolher em Blumenau (SC), compreendem que, neste contexto, a medida seria "mais um passo no gradual retorno da visão autoritária na política de atendimento à infância”. Após uma análise histórica das políticas públicas para a infância no Brasil do século XIX, seguida de uma verificação do contexto de Blumenau, os autores concluem que "o trato repressor e policialesco em relação à criança de família pobre não se esgotou nem desapareceu com a promulgação do ECA". Os autores chamam atenção para o fato de que, embora se apresente como uma proposta neutra/universalista, a "questão social da criança" trata-se de um processo fundamentalmente político e com caráter de classe, já que seria uma forma de controle social das crianças pobres pelo Estado, "protegendo" a sociedade ${ }^{60}$.

Para Mauro Campello, as portarias judiciais que estabelecem o toque de re-

\footnotetext{
${ }^{59}$ MÉNDEZ, Emilio García. La Convención Internacional de los derechos de la infancia: del menor como objeto de la compasión-represión a la infancia-adolescencia como sujeto de derechos. Nuevo Foro Penal, $\mathrm{n}^{\circ} 57$, Julio, 1992, p. 422.

${ }^{60}$ MARCHI, Rita de Cássia; SOUZA, Josué de. O "Toque de recolher" como um retrocesso ao autoritarismo: caminhos e tendências políticas do Conselho Tutelar em Blumenau. Emancipação, Ponta Grossa, v. 12, n. 1, 2012, p. 99. Disponível em: < http://www.revistas2.uepg.br/index.php/emancipacao/article/view/1805/3128> . Acesso em: 25 jun. 2018.
} 
colher "trazem uma taxação generalizada de periculosidade sobre os meninos de/na rua, a fim de legitimar ações estatais repressivas de caráter limitadoras dos direitos fundamentais, com a fixação de horário para crianças e adolescentes estarem nas ruas das cidades" ${ }^{61}$. Assim, para o autor,

Essas ferramentas judiciais, na prática, lançaram na vala comum todos os jovens que após as $23 \mathrm{~h}$ estejam em logradouros públicos desacompanhados de seus pais ou de responsável, antes que seus comportamentos violassem norma penal incriminadora (ato infracional). Elas atingem diretamente seus pensamentos. A periculosidade lançada sobre todos os meninos de/na rua nada mais é que uma prognose. Relaciona-se à provável prática de um fato delituoso quando estiverem nas ruas, especialmente depois das $23 \mathrm{~h}$. Lógica esta que remonta ao século XIX e desenvolvida no século XX, até 1990, quando a doutrina da proteção integral quebrou tal modelo, mediante a vigência do ECA. Aceitar tal medida é esconder, atrás do discurso da prevenção de ação futura, da vigilância e da assistência às crianças e adolescentes de/na rua, uma ideologia patrimonialista e, sobretudo, preconceituosa, para punir o jovem pelo que ele é e não pelo que ele fez ${ }^{62}$.

Nesta mesma linha de raciocínio, Méndez compreende que "onde imperam leis de menores pseudotutelares, baseadas na doutrina da situação irregular, não se distinguem as infrações à lei penal (atos tipicamente antijurídicos e culpados) de outros comportamentos antissociais, porém irrelevantes do ponto de vista jurídico"63. Acerca da responsabilidade penal dos adolescentes, o autor explica que

A partir da aprovação do "Estatuto da Criança e do Adolescente" - ECA - no Brasil, em 1990, todas as novas legislações latino-americanas contemplaram (com maior ou menor refinamento técnico) a criação de um modelo jurídico-institucional de res-

${ }^{61}$ CAMPELLO, Mauro José do Nascimento. A lógica que se esconde na Portaria "Toque de recolher" baixada pelo Estado-Juiz. Examãpaku. Revista Eletrônica de Ciências Sociais, História e Relações Internacionais (UFRR), v. 5, n. 1, 2012, p. 20. Disponível em: < https://revista.ufrr.br/examapaku/article/view/1447>. Acesso em: 25 jun. 2018.

${ }^{62}$ CAMPELLO, Mauro José do Nascimento. A lógica que se esconde na Portaria "Toque de recolher" baixada pelo Estado-Juiz. Examãpaku. Revista Eletrônica de Ciências Sociais, História e Relações Internacionais (UFRR), v. 5, n. 1, 2012, p. 20. Disponível em: < https://revista.ufrr.br/examapaku/article/view/1447> Acesso em: 25 jun. 2018.

${ }^{63}$ MÉNDEZ, Emilio García. A Dimensão Política da Responsabilidade Penal dos Adolescentes na América Latina: notas para a construção de uma modesta utopia. Educação \& Realidade, v. 33, n. 2, jul./dez. 2008, p. 16. Disponível em: < http://seer.ufrgs.br/index.php/educacaoerealidade/article/view/7061/4377> . Acesso em: 01 jul. 2018. 
ponsabilidade penal aplicado aos adolescentes (de doze ou quatorze anos de idade até dezoito anos incompletos). A base jurídica imediata e direta desse modelo foram os artigos 37 e 40 da CIDC. O conteúdo essencial dessa transformação pode ser explicado em poucas e simples palavras: os adolescentes deixam de ser responsáveis penalmente pelo que são (é bom lembrar que a dimensão penal da responsabilidade deve ser medida pelas consequências reais que gera e não pelo mero discurso declarado), para começar a sê-lo unicamente pelo que fazem e isso só quando esse fazer implica uma infração às normas penais. Esse processo foi e continua sendo extremamente difícil e complexo (grifo nosso) ${ }^{64}$.

Um olhar histórico sobre o controle social da infância permite constatar que, pelo menos desde o século XIX, este controle é feito de forma repressiva pelo Estado. A distinção entre criança e menor e a associação entre pobreza e delinquência contribuíram para esse modelo de intervenção, que perdura até hoje. Não obstante as modificações na legislação no sentido de uma proteção integral - que, no caso brasileiro, se deram pela Constituição Federal de 1988 e pelo Estatuto da Criança e do Adolescente -, as práticas dos juízes das varas da infância e da juventude - bem como de conselheiros tutelares, promotores, policiais etc. - insistem na ideia de punição de atos "antissociais", mesmo que estes não impliquem infrações à lei penal. Em outras palavras, mesmo em um modelo de proteção integral, os profissionais que atuam na área da infância e adolescência continuam reproduzindo a doutrina da situação irregular, punindo os jovens pelo que eles são, e não pelo que eles fizeram. Assim, embora os defensores do toque de recolher aleguem que a restrição seria uma medida protetiva e preventiva, compreende-se aqui tratar-se antes de uma prática repressiva.

Outro problema relacionado ao tema se refere aos limites do poder da autoridade judiciária. Os defensores da medida argumentam, conforme visto anteriormente, que o poder para editar as portarias judiciais do toque de recolher estaria no próprio ECA, principalmente em seu artigo 149. Destaque-se, todavia, que as hipóteses previstas no referido artigo são taxativas, e que o dispositivo não permite que os juízes estabeleçam portarias acerca de quaisquer questões, pois isso equivaleria a conferir à autoridade judiciária competência para legislar.

\footnotetext{
${ }^{64}$ MÉNDEZ, Emilio García. A Dimensão Política da Responsabilidade Penal dos Adolescentes na América Latina: notas para a construção de uma modesta utopia. Educação \& Realidade, v. 33, n. 2, jul./dez. 2008, p. 21. Disponível em: < http://seer.ufrgs.br/index.php/educacaoerealidade/article/view/7061/4377> . Acesso em: 01 jul. 2018.
} 
A competência normativa da Justiça da Infância e da Juventude está restrita às hipóteses taxativamente relacionadas no art. 149, do ECA, que de maneira expressa veda determinaçóes de caráter geral (cf. parágrafo segundo do citado dispositivo), posto que não cabe à autoridade judiciária "legislar" e, muito menos, decidir de forma contrária à lei e à Constituição Federal. Fora das hipóteses restritas do art. 149, incisos I e II, do ECA, portanto, o Juiz da Infância e da Juventude não tem competência para expedição de portarias e alvarás, e qualquer ato judicial que extrapole os referidos parâmetros/ limites legais será nulo de pleno direito. Assim sendo, não há mais lugar para práticas arbitrárias de outrora, como os famigerados "toques de recolher" que, embora bastante comuns à época do revogado "Código de Menores", hoje violam de forma expressa não apenas o âmbito da competência normativa da Justiça da Infância e da Juventude, mas as próprias disposições contidas nos arts. $3^{\circ}, 4^{\circ}$, caput, $5^{\circ}, 15,16$, inciso I e 18, do ECA, bem como o disposto no art. $5^{\circ}$, inciso XV, da CF (que assegura a todos, independentemente da idade, o direito de ir e vir dentro do território nacional). Importante observar que, mesmo nas hipóteses em que a lei confere à Justiça da Infância e da Juventude a competência para expedir portarias e alvarás, a atividade jurisdicional deve ser exercida com a estrita observância de determinadas regras e parâmetros, mais uma vez sob pena de nulidade do ato respectivo. As únicas hipóteses que admitem a regulamentação judicial via portaria são aquelas expressamente relacionadas no inciso I deste dispositivo, não tendo a autoridade judiciária competência para abranger situações ali não contempladas (grifos no original) ${ }^{65}$.

$\mathrm{O} \S 2^{\circ}$ do art. 149 reforça a necessidade de que as portarias sejam fundamentadas, sendo vedadas as determinações de caráter geral. Acerca desse dispositivo, Murillo José Digiácomo e Ildeara de Amorim Digiácomo explicam que "o Juiz da infância e da juventude, mesmo quando no exercício desta competência sui generis, estará no pleno exercício de sua atividade jurisdicional (e não administrativa ou 'legiferante'), pelo que aplicáveis os mesmos princípios (e restrições) que regem a jurisdição" ${ }^{\prime 66}$.

${ }_{65}$ DIGIÁCOMO, Murillo José; DIGIÁCOMO, Ildeara de Amorim. Estatuto da criança e do adolescente anotado e interpretado. $7^{\mathrm{a}} \mathrm{ed}$. Curitiba: Ministério Público do Estado do Paraná. Centro de Apoio Operacional das Promotorias da Criança e do Adolescente, 2017, p. 276.

${ }^{66}$ DIGIÁCOMO, Murillo José; DIGIÁCOMO, Ildeara de Amorim. Estatuto da criança e do adolescente anotado e interpretado. $7^{\mathrm{a}} \mathrm{ed}$. Curitiba: Ministério Público do Estado do Paraná. Centro de Apoio Operacional das Promotorias da Criança e do Adolescente, 2017, p. 279. 
Conforme visto anteriormente, a prática do toque de recolher é justificada juridicamente pelos aplicadores da medida com base no Estatuto da Criança e do Adolescente. Todavia, defende-se aqui que a limitação do horário de circulação dos jovens deva ser fruto de uma maior reflexão, com o objetivo de verificar se estas interpretações dos dispositivos do ECA estão de acordo com a proposta de proteção integral trazida pela legislação atual.

Frederico Marinho e Joana Vargas ${ }^{67}$ - em artigo que analisa como as mudanças legislativas impactaram na gestão e no tratamento da delinquência juvenil no Brasil e na França - chamam atenção para o "gap" entre legislação e práticas na área da infância e juventude. Segundo os autores,

No Brasil, apesar dos discursos oficiais, o caráter liberal e progressista da legislação apresenta grande dificuldade de se integrar às práticas das organizaçóes e dos profissionais responsáveis pelos adolescentes infratores. Na França, ao contrário, desde a década de 1990, após as sucessivas alterações e retificações, afirma-se que a execução das políticas criminais tem sido mais liberal do que a legislação. Nesse sentido, parece interessante analisar as respostas oferecidas pelos dois campos sociojudiciários, um de tradição tutelar e outro misto, não apenas com base nas legislações de cada país, mas também nas representações e práticas adotadas e, principalmente, na descrição e análise dos conflitos e disputas inerentes ao campo (grifo nosso) ${ }^{68}$.

Assim, entende-se que, para a compreensão das discussões que hoje se apresentam no Direito da Criança e do Adolescente - como, por exemplo, o debate sobre o toque de recolher -, são necessários não apenas estudos sobre os dispositivos da Lei 8.069/1990, mas, principalmente, análises sobre os profissionais - juízes, promotores, policiais, conselheiros tutelares etc. - que atuam nesta área, tendo em vista que eles são os responsáveis por materializar a ideia de proteção integral presente no ECA. Conhecer as práticas destes profissionais é fundamental para a descoberta - e para a crítica eficaz - dos arranjos que estão sendo feitos cotidianamente na área da infância e juventude.

\footnotetext{
${ }^{67}$ MARINHO, Frederico Couto; VARGAS, Joana Domingues. Permanências e resistências: legislação, gestão e tratamento da delinquência juvenil no Brasil e na França. Dilemas: Revista de Estudos de Conflito e Controle Social, Rio de Janeiro, Edição Especial n. 1, p. 267-298, 2015.

${ }^{68}$ MARINHO, Frederico Couto; VARGAS, Joana Domingues. Permanências e resistências: legislação, gestão e tratamento da delinquência juvenil no Brasil e na França. Dilemas: Revista de Estudos de Conflito e Controle Social, Rio de Janeiro, Edição Especial n. 1, 2015, p. 272.
} 


\section{CONSIDERAÇÕES FINAIS}

Embora a discussão sobre as portarias judiciais que estabelecem o toque de recolher não seja muito recente, já que se tem notícia desta prática em municípios brasileiros pelo menos desde 2005, trata-se de um assunto ainda bastante debatido.

Em 2012, o STJ manifestou-se contrariamente à medida e, mesmo após esta decisão, a restrição continua sendo aplicada em muitas cidades, através de portarias judiciais. Em outros municípios, conforme foi visto, embora não exista a restrição por iniciativa da autoridade judiciária, existem projetos de lei que objetivam estabelecer o toque de recolher. Estas últimas hipóteses, todavia, foram vistas apenas de forma exemplificativa neste artigo, já que o objeto desta pesquisa consistiu no toque de recolher implementado através de portarias de magistrados que atuam na área da infância e juventude. Apesar de muitos argumentos contrários ou favoráveis à restrição servirem para ambas as situações - ou seja, tanto para o toque de recolher por iniciativa de juízes quanto para aquele implementado em razão de lei -, o caso das portarias judiciais apresenta dificuldades adicionais, pois exige um debate acerca dos limites dos poderes dos magistrados.

Na seção 3 foram apresentados os argumentos comumente utilizados pelos magistrados no estabelecimento do toque de recolher em suas comarcas. Observou-se que as justificativas para as restrições alternam entre argumentos de caráter técnico-jurídico - concordância da medida com a lei - e argumentos fáticos como, por exemplo, a diminuição de atos infracionais. No que se refere aos argumentos jurídicos, os juízes utilizam como base o próprio ECA, em especial o artigo 149 que, para os defensores da medida, elencaria hipóteses não taxativas, permitindo que os magistrados estabelecessem, através de portarias, limitações às crianças e adolescentes além daquelas descritas nos incisos do referido artigo. Ademais, os defensores do toque de recolher argumentam que a medida não configuraria uma ofensa ao direito de ir e vir das crianças e adolescentes, acrescentando que diversas restrições estariam presentes no ECA. Por fim, defendem que o toque de recolher seria uma medida protetiva e preventiva.

Na sequência, foi feita uma comparação entre o Estatuto da Criança e do Adolescente e o revogado Código de Menores (Lei no 6.697/1979), no que se refere à amplitude dos poderes conferidos aos magistrados que atuam na área da infância e juventude. Constatou-se, a partir de um breve histórico legislativo, que o ECA con- 
feriu à autoridade judiciária um poder menor do que aquele conferido ao juiz pelas legislações anteriores, de 1979 e de 1927.

Por fim, foi apresentado um debate teórico sobre o tema. Concluiu-se que, mesmo com as alterações trazidas pelo ECA - no sentido de uma proteção integral da criança e do adolescente, e também no sentido de uma diminuição dos poderes da autoridade judiciária -, os profissionais que atuam na área da infância e juventude continuam reproduzindo práticas contemporâneas ao revogado Código de Menores, baseadas na doutrina da situação irregular. Isso fica evidente no caso do toque de recolher, na medida em que se trata de um controle social feito de forma repressiva, e tendo como base não aquilo que as crianças e os adolescentes fizeram, mas aquilo que ele são. Ademais, a autoridade judiciária, neste caso, exorbita os poderes conferidos a ela - já que as hipóteses do art. 149 do ECA são taxativas -, aproximando-se do modelo de juiz presente na legislação anterior.

Destaque-se, ainda, a necessidade de pesquisas que investiguem a atuação profissional de juízes, promotores, policiais, conselheiros tutelares e demais atores que trabalham na área da infância e adolescência. Tendo em vista que estes profissionais são os responsáveis por materializar a ideia de proteção integral presente no ECA, conhecer suas práticas é fundamental para um avanço no debate acerca de temas polêmicos que se apresentam na área.

\section{REFERÊNCIAS}

ALMEIDA, Fernanda Andrade. O juiz "bicho-papão" e a "lei em movimento": um caso de judicialização à brasileira. Niterói: UFF, 2013. Tese de Doutorado - Programa de Pós-Graduação em Sociologia e Direito, Universidade Federal Fluminense.

BAHIA NOTÍCIAS. Antas: Juiz implanta "hora de acolher" que restringe permanência de menores nas ruas. 04 nov. 2016. Disponível em: <http://www. bahianoticias.com.br/justica/noticia/55521-antas-juiz-implanta-039hora-de-acolher039-que-restringe-permanencia-de-menores-nas-ruas.html>. Acesso em: 05 jan. 2017.

BRASIL. Código de Menores. Lei n ${ }^{\circ} 6.697$, de 10 de outubro de 1979. Institui o Código de Menores. Diário Oficial da União, Brasília, p. 14945, 11 out. 1979a. Disponível em: <http://www.planalto.gov.br/ccivil_03/leis/1970-1979/L6697impressao. 
htm >. Acesso em: 24 nov. 2012.

BRASIL. Código dos Menores. Decreto no 17.943-a de 12 de outubro de 1927. Consolida as leis de assistência e proteção a menores. Coleção das Leis do Brasil, Poder Executivo, Rio de Janeiro, 31 dez. 1927. Disponível em: < http://www.planalto. gov.br/ccivil_03/decreto/1910-1929/D17943Aimpressao.htm>. Acesso em: 24 nov. 2012.

BRASIL. Congresso Nacional. Câmara dos Deputados. Comissão de Seguridade Social e Família (CSSF). Parecer sobre o Projeto de Lei 4.590/2012. Dispõe sobre a permanência de crianças e adolescentes após as vinte e duas horas, nos locais que especifica. Brasília, 29 nov. 2016. Disponível em: < http://www.camara.gov.br/ proposicoesWeb/prop_mostrarintegra?codteor $=1511467 \&$ filename $=$ Tramitacao-PL+4590/2012 > . Acesso em: 06 jan. 2017.

BRASIL. Congresso Nacional. Câmara dos Deputados. Projeto de Lei 2540/1979. Introduz alterações na Lei 6697, de 10 de outubro de 1979 (Código de Menores). Brasília, 04 dez. 1979b. Disponível em:

$<$ http://www.camara.gov.br/proposicoesWeb/fichadetramitacao?idProposicao $=204430>$. Acesso em: 24 nov. 2012.

BRASIL. Congresso Nacional. Câmara dos Deputados. Projeto de Lei 4.590/2012. Dispõe sobre a permanência de crianças e adolescentes após as vinte e duas horas, nos locais que especifica. Brasília, 23 out. 2012. Disponível em: < http:// www.camara.gov.br/proposicoesWeb/prop_mostrarintegra;jsessionid $=104 \mathrm{E} 577 \mathrm{BE}$ DE0D9A0F8EC37506789AC51.proposicoesWebExterno1? codteor $=1032716 \&$ filename $=P L+4590 / 2012>$. Acesso em: 06 jan. 2017.

BRASIL. Emenda Constitucional $\mathrm{n}^{0} 1$, de 17 de outubro de 1969. Edita o novo texto da Constituição Federal de 24 de janeiro de 1967. Diário Oficial da União, 20 out. 1969. Disponível em: < http://www.planalto.gov.br/ccivil_03/Constituicao/Emendas/Emc_anterior1988/emc01-69.htm> Acesso em: 24 nov. 2012.

BRASIL. Estatuto da Criança e do Adolescente. Lei no 8.069, de 13 de julho de 1990. Dispõe sobre o Estatuto da Criança e do Adolescente e dá outras providências. Diário Oficial [da] República Federativa do Brasil, Brasília, p. 13563, 16 jul. 1990. Disponível em: < http://www.planalto.gov.br/ccivil_03/leis/18069.htm > . Acesso em: 24 nov. 2012. 
BRASIL. Superior Tribunal de Justiça. Primeira Turma. Acórdão. Recurso Especial 1.292.143/SP. Recorrente: Ministério Público do Estado de São Paulo. Recorrido: Estado de São Paulo. Relator: Teori Albino Zavascki. Data de Julgamento: 21 jun. 2012. Diário da Justiça Eletrônico (DJe): 07 ago. 2012. Disponível em: <http://www.stj.jus.br/webstj/processo/Justica/detalhe. asp? numreg $=201102619325 \& \mathrm{pv}=000000000000>$. Acesso em: 28 set. 2012.

CAMPELLO, Mauro José do Nascimento. A lógica que se esconde na Portaria "Toque de recolher" baixada pelo Estado-Juiz. Examãpaku. Revista Eletrônica de Ciências Sociais, História e Relações Internacionais (UFRR), v. 5, n. 1, p. 1-22, 2012. Disponível em: < https://revista.ufrr.br/examapaku/article/view/1447>. Acesso em: 25 jun. 2018.

CONSELHO NACIONAL DE JUSTIÇA. Agência CNJ de Notícias. Toque de recolher: comissão do CNJ vai analisar regras para edição de portarias. Notícias, Brasília, 10 nov. 2009. Disponível em: < http://www.cnj.jus.br/component/content/article/ 96-noticias/7902-toque-de-recolher-comissao-do-cnj-vai-analisar-regras-para-edicao-de-portarias > . Acesso em: 30 nov. 2009.

CORREIO DA CIDADE. Juiz implanta toque de acolher em Cícero Dantas, na Bahia. 16 nov. 2016. Disponível em: < http://www.correiodacidade.com.br/noticia/12951/juiz-implanta-toque-de-acolher-em-c-cero-dantas-na-bahia $>$. Acesso em: 05 jan. 2017.

CURY, Munir; SILVA, Antônio Fernando do Amaral e; MENDEZ, Emílio García (Coord.). Estatuto da Criança e do Adolescente Comentado: Comentários Jurídicos e Sociais. São Paulo: Malheiros, 1992.

CUSTÓDIO, André Viana. Teoria da Proteção Integral: pressuposto para compreensão do Direito da Criança e do Adolescente. Revista do Programa de Pós-Graduação em Direito - Mestrado e Doutorado da Universidade de Santa Cruz do Sul, Santa Cruz do Sul, n. 29, Jan-Jun/2008, p. 22-43. Disponível em: < http://online. unisc.br/seer/index.php/direito/article/view/657/454>. Acesso em: 03 nov. 2015.

DIGIÁCOMO, Murillo José; DIGIÁCOMO, Ildeara de Amorim. Estatuto da criança e do adolescente anotado e interpretado. $7^{\mathrm{a}}$ ed. Curitiba: Ministério Público do Estado do Paraná. Centro de Apoio Operacional das Promotorias da Criança e do Adolescente, 2017. 
G1. Prefeitura protocola ação contra "toque de recolher" em Guarapari. 02. abr. 2014. Disponível em: < http://g1.globo.com/espirito-santo/noticia/2014/04/prefeitura-protocola-acao-contra-toque-de-recolher-em-guarapari.html $>$. Acesso em: 06 jan. 2017.

G1. Toque de recolher a menores de $\mathbf{1 6}$ anos gera polêmica no ES. 01 abr. 2014. Disponível em: < http://g1.globo.com/espirito-santo/noticia/2014/04/toque-de-recolher-menores-de-16-anos-gera-polemica-no-es.html> . Acesso em: 06 jan. 2017.

GUIMARÃES, Thiago. 72 cidades do Brasil adotam toque de recolher para crianças e jovens, diz juiz. Justiça Atuante (Blog), Itapicuru (BA), 09 jun. 2011. Disponível em: ～< http://justicaatuante.blogspot.com.br/2011/06/72-cidades-do-brasil-adotam-toque-de.html> . Acesso em: 8 dez. 2011.

MARCHI, Rita de Cássia; SOUZA, Josué de. O "Toque de recolher" como um retrocesso ao autoritarismo: caminhos e tendências políticas do Conselho Tutelar em Blumenau. Emancipação, Ponta Grossa, v. 12, n. 1, p. 87-101, 2012. Disponível em: $<$ http://www.revistas2.uepg.br/index.php/emancipacao/article/view/1805/3128>. Acesso em: 25 jun. 2018.

MARINHO, Frederico Couto; VARGAS, Joana Domingues. Permanências e resistências: legislação, gestão e tratamento da delinquência juvenil no Brasil e na França. Dilemas: Revista de Estudos de Conflito e Controle Social, Rio de Janeiro, Edição Especial n. 1, p. 267-298, 2015.

MÉNDEZ, Emilio García. A Dimensão Política da Responsabilidade Penal dos Adolescentes na América Latina: notas para a construção de uma modesta utopia. Educação \& Realidade, v. 33, n. 2, p. 15-36, jul./dez. 2008. Disponível em: < http://seer. ufrgs.br/index.php/educacaoerealidade/article/view/7061/4377>. Acesso em: 01 jul. 2018.

MÉNDEZ, Emilio García. La Convención Internacional de los derechos de la infancia: del menor como objeto de la compasión-represión a la infancia-adolescencia como sujeto de derechos. Nuevo Foro Penal, n 57, p. 421-432, Julio, 1992.

NETTO, José Brandão. 78 cidades já possuem o "toque de acolher" ou recolher. Justiça Atuante (Blog), Itapicuru (BA), 06 jun. 2011. Disponível em: < http://toquedeacolherbahia.blogspot.com.br/2011/06/78-cidades-ja-possuem-o-de-acolher-ou. html> . Acesso em: 8 dez. 2011. 
O POPULAR DO PARANÁ. Araucária agora tem "toque de recolher" para menores. 23 out. 2015. Disponível em: < http://www.opopularpr.com.br/geral/araucaria-agora-tem-toque-de-recolher-para-menores/> . Acesso em: 05 jan. 2017.

O POVO. Juiz determina "toque de recolher" para crianças e adolescentes em Graça. 30 abr. 2014. Disponível em: < http://www.opovo.com.br/app/fortaleza/2014/04/30/noticiafortaleza,3243955/juiz-determina-toque-de-recolher-para-criancas-e-adolescentes-em-graca.shtml> . Acesso em: 05 jan. 2017.

SÃO PAULO (Estado). Tribunal de Justiça do Estado de São Paulo. Comarca de Fernandópolis. $1^{\text {a }}$ Vara Criminal e Anexo da Infância e da Juventude. Informações do magistrado nos autos do PCA 2009.10.00.003736-7. Fernandópolis, 18 set. 2009a.

SÃO PAULO (Estado). Tribunal de Justiça do Estado de São Paulo. Comarca de Fer-

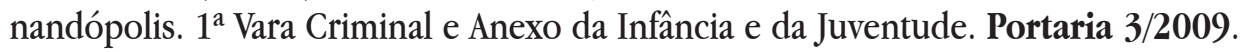
Fernandópolis, 23 mar. 2009b.

SÃO PAULO (Estado). Tribunal de Justiça do Estado de São Paulo. Comarca de Ilha Solteira. Vara Única. Portaria do Juiz de Direito. Sobre a limitação de horários de circulação de crianças e adolescentes na Comarca. Ilha Solteira, 2009c. Disponível em: < http://www.ilhasolteira.sp.gov.br/documentos/toque_de_recolher.pdf $>$. Acesso em: 10 dez. 2009.

SENADO FEDERAL. Subsecretaria de Edições Técnicas. Código de Menores. Lei $\mathrm{n}^{\mathrm{o}}$ 6.697/79, comparações, anotações, histórico, por Ana Valderez A. N. de Alencar e Carlos Alberto de Sousa Lopes. Brasília, Senado Federal, 1982.

SIQUEIRA, Chico. Juiz diz que Conselho não derruba toque de recolher. Notícias Terra, Araçatuba, 05 jul. 2009. Disponível em: < http://noticias.terra.com. $\mathrm{br} / \mathrm{brasil} /$ noticias/0,,OI3857319-EI8139,00-Juiz + diz + que + conselho + nao + derruba + toque + de + recolher.html $>$. Acesso em: 18 out. 2010. 